Andrew Young School of Policy Studies Research Paper Series

Working Paper 07-06

March 2007

Department of Economics

\title{
The Knowledge Production Function for University Patenting
}

\author{
Paula Stephan \\ Georgia State University
}

Grant Black Indiana University South Bend

Shiferaw Gurmu Georgia State University

This paper can be downloaded at:

http://aysps.gsu.edu/publications/2007/index.htm

The Social Science Research Network Electronic Paper Collection: http://ssrn.com/abstract=975786 


\title{
The Knowledge Production Function for University Patenting
}

\author{
PAULA STEPHAN*, GRANT BLACK** and SHIFERAW GURMU* \\ *Andrew Young School of Policy Studies, Georgia State University \\ **School of Business and Economics, Indiana University South Bend
}

Contact information: Stephan: Department of Economics, Andrew Young School of Policy Studies, P.O. Box 3992, Georgia State University, Atlanta, GA, 30302. E-mail pstephan@gsu.edu, Phone 404-651-9388, Fax 404-651-4985.

Black: E-mail gcblack@iusb.edu, Phone 574-520-5541, Fax 574-520-4866

Gurmu: E-mail sgurmu@gsu.edu, Phone 404-651-1907, 404-651-4985.

The authors wish to thank Bhaven Sampat for generously sharing his university patent data with us and Jerry Thursby for sharing AUTM data with us. Financial support for this project was received from the Science and Engineering Workforce Project, National Bureau of Economic Research. All errors are those of the authors. The use of NSF data does not imply NSF endorsement of the research methods or conclusions contained in the paper. 


\begin{abstract}
We estimate a knowledge production function for university patenting using an individual effects negative binomial model. We control for R\&D expenditures, research field and the presence of a TTO office. We distinguish between three kinds of researchers who staff labs: faculty, postdoctoral students and $\mathrm{PhD}$ students. We also examine whether PhDs and postdoctoral scholars contribute equally to patent activity or whether there is a differential effect depending upon visa status. We find patent counts relate positively and significantly to the number of faculty, number of PhD students and number of postdocs. Our results also suggest that not all graduate students and postdocs contribute equally to patenting but that contribution is mediated by visa status.
\end{abstract}

JEL Code: O31, O32, O34, O38, C23.

Key Words: Academic Patenting; Technology transfer; Count panel data; Bayh-Dole Act; Knowledge Transfer; Knowledge production function; competitiveness; international students. 


\section{Introduction}

Following the work of Zvi Grililiches (1979), it has become standard practice to speak of the knowledge production function. Numerous studies have estimated various forms of the function, focusing on industry. More recently, considerable interest has arisen regarding innovative activity occurring in the university sector. Much of this work focuses on university patenting, about which we now know a considerable amount. For example, we know which universities produce the most patents, which receive the most in licensing revenue, and in what fields patents are most likely to be issued. We know something about the incentive structure related to royalty payments, how patenting relates to individual characteristics and whether there is evidence supporting the anti-commons hypothesis that patenting crowds out subsequent research destined for the public domain. But oddly enough, in light of the considerable body of work regarding the knowledge production function in industry, we know less about the knowledge production function for university patents.

This paper addresses this deficiency and estimates the knowledge production function for university patenting. A key input in the patenting process, and one that we pay particular attention to in this work, are the researchers who staff university laboratories. While some of these scientists are permanent employees, the vast majority are pre and postdoctoral students. This is readily seen by an examination of the web pages of faculty labs. It is particularly characteristic of research in the United States where historically the paradigm has been to staff laboratories with temporary workers (Stephan and Levin 2001a).

Here we estimate a knowledge production function for university patenting during the period 1985-1999. The unit of analysis is the number of patents issued to university $\mathrm{x}$ at time period $t$ in one of five fields. We relate this patent activity to $R \& D$ expenditure data, number of faculty, and number of postdoctoral students and PhD students studying at the university in the specified field during the time the patent research was undertaken. One issue of interest to us is whether all PhDs and postdoctoral scholars (postdocs) contribute equally to patent activity or whether there is a differential effect depending upon visa status. This is a question of considerable policy concern given recent changes in immigration policy following $9 / 11$ and the general lack of interest shown among U.S. 
citizens (and especially white males) in pursuing $\mathrm{PhD}$ training in the sciences in recent years.

We find that patent output relates positively and significantly to the stock of R\&D expenditures and the presence of a TTO office. The R\&D expenditure elasticity is around .30. We find the human resource variables to be positive and significant: patent counts relate positively and significantly to the number of faculty, number of $\mathrm{PhD}$ students and number of postdocs. When we differentiate according to visa status, our results suggest that not all graduate students contribute equally to patenting. There is a positive and significant relationship between patenting and citizen-PhD students and a negative and significant relationship between temporary-resident PhD students and patenting. The coefficients on the two variables differ significantly from each other using traditional levels of significance. On the other hand, there is a clear and strong relationship between patents and the number of postdoctoral students on temporary visas. We find no such relationship between patenting and the number of citizen and permanent resident postdocs working at the university.

The plan of this paper is as follows. In section two we summarize the growing role that universities are playing in the intellectual property arena. Section three discusses the laboratory culture that exists at universities in the U.S., placing special emphasis on the role that PhDs and postdocs play in the research process. Section four examines what has happened to $\mathrm{PhD}$ production over time, as well as to the number of postdoctoral students working in academe. Special emphasis is placed on how graduate and postdoctoral participation overtime has varied by visa status. Section five summarizes research to date concerning whether the foreign-born contribute disproportionately to innovation in the United States. The data and estimation methods are summarized in Section 6; the results are presented in Section 7. Conclusions are drawn in Section 8.

\section{The Role that Universities Play in Patenting}

Patenting activity is not new to the university. Isolated instances of a university (or university-related foundation) applying for and receiving a patent go back almost 100 
years. ${ }^{1}$ What is new is the rate at which patenting activity is occurring at the university. While some attribute this dramatic increase to the passage of the Bayh-Dole Act, Mowery and co-authors (2004) argue that it is more complex and that the increase in patenting can be detected prior to the passage of Bayh-Dole, especially in the decade prior to passage of the act. $^{2}$

Figure 1 plots the dramatic increase in patenting activity that has occurred in recent years at universities. While fewer than 200 patents were issued in 1969, by 1997 the number had risen to almost 2500. In 2003 the number stood at over $3400^{3}$ (National Science Board 2006, Table 5-28). The increase in patenting activity has come both from an increase in patenting activity at campuses with a tradition of patenting as well as the increase in the number of universities with technology transfer offices (TTO). By way of example, while fewer than 10 universities had a technology transfer office in 1970, by 1980 around 70 had TTOs and approximately 200 had TTOs by $1995 .^{4}$

\section{The Role that Doctoral Students and Postdoctoral Students Play in Research}

Graduate students and more recently postdoctoral students play a key role in staffing research laboratories at U.S. universities. This is in contrast to many laboratories in Europe where labs are staffed primarily with permanent appointments. ${ }^{5}$ This way of staffing labs has been embraced in the U.S. for a variety of reasons. Pedagogically, it is an efficient training model. It is also an inexpensive way to staff laboratories. Moreover, and as faculty are not unabashed to note, it provides a source of "new” ideas, especially given the age of doctoral students and postdocs. To quote Trevor Penning, the Associate Dean for Postdoctoral Research Training at the time at the University of Pennsylvania

\footnotetext{
${ }^{1}$ See Mowery et al (2004 p. 38-39) for a discussion of early university patenting activity. The authors note that land-grant institutions, which conducted a good deal of applied research, were the first group of universities to become involved in patents. While a number of these universities sought patents for faculty inventions, land-grant institutions frequently "outsourced" their patent management to affiliated but legally separate foundations or to the Research Corporation, a third-party technology transfer agent.

${ }^{2}$ By way of example, the Cohen-Boyer patent was applied for in 1974, six years before the passage of the act.

${ }^{4}$ The TTO counts, which come from AUTM data, were provided by Jerry Thursby.

${ }^{5}$ Many university faculty in Europe hold appointments both in government research laboratories and as university faculty. For example, in France it is common to hold both a CNRS (Centre National da la Recherche Scientifique) appointment and a university appointment, with the laboratory expenses being borne by CNRS.
} 
School of Medicine, "A faculty member is only as good as his or her best postdoc" (Penning 1998). In addition, funding is often more readily available for pre-doctoral and postdoctoral students than for staff scientists. The typical NIH grant, for example, supports both types of training as do many other forms of grants. At least from NSF's perspective, it has been a conscious policy to fund students. Rita Colwell, the Director of the National Science Foundation from 1998-2004, said in an interview with Science that "In the 1980s, NSF asked investigators to put graduate students on their research budgets, saying it preferred to fund graduate students rather than technician.” (Science 1998).

There is also the added advantage that postdocs and graduate students, with their short tenure, provide for more flexibility in the staffing of laboratories than do permanent technicians.

One indication of the important role that pre-doctoral and post-doctoral students play in staffing labs is given in a recent dataset assembled by Tanwin Chang (2006) to study laboratories doing work in nanotechnology. Chang found information on the internet on laboratory staffing for 415 faculty researchers affiliated with a nanoscience center at one of fourteen academic institutions. ${ }^{6}$ The median number of technical staff was 11 (including the faculty member); the mean number 13. A sizeable number of the technical staff were graduate students and postdocs. Specifically, Chang identified 2506 graduate students and 821 postdoctoral students working in one of the 415 labs. He also documented 507 undergraduate students affiliated with these labs. This means that 78.1\% of the lab staff (excluding faculty) was made up of individuals in training: $51.4 \%$ graduate students; $16.5 \%$ postdoctoral students; $10.2 \%$ undergraduate students. The remaining 22\% supposedly represent more permanent technical staff.

\footnotetext{
${ }^{6}$ The affiliated campuses and names of the nano centers/institutes/teams are CBEN, CNST (Rice); Center for Nanoscale Devices, Network for Computational Nanotechnology: NanoHub, NASA Institute for Nanoelectronics and Computing (Purdue); NSEC, Center for Nanoscale Systems (Harvard); NanoBiotechnology Center, Center for Nanoscale Systems, (Cornell); Center for NanoScience and Technology (Notre Dame); CNSI (UCLA); CNSI (UCSB); College for Nanoscience (SUNY Albany); Institute for Nanotechnology, Nanoscale Interdisciplinary Research Team (Northwestern); Institute for Soldier Nanotechnologies (MIT); MRSEC Center for Nanostructured Materials, NSEC for Electron Transport in Molecular Nanostructures (Columbia); NSEC for Directed Assembly of Nanostructures (RPI); NSEC on Templated Synthesis and Assembly at the Nanoscale (U. of Wisconsin, Madison); The Center for Nanotechnology (University of Washington).
} 


\section{Trends in the Production of PhDs and Postdoctoral Students}

\subsection{PhD Awards 1981-1999}

In the early 1980s, the U.S. was producing approximately 11,000 PhDs annually in science and engineering. By the late 1990s this figure had grown to almost 19,000, increasing by about $72 \%$. This substantial increase, however, masks wide differences in enrollment patterns among U.S. citizens and non-citizens. Attracted by fields such as medicine, law and business, the number of U.S. students going into PhD programs grew by only 25\% during the period 1981-1999. Moreover, much of this growth was among women students; the number of males receiving $\mathrm{PhDs}$ in science and engineering grew only marginally during the period.

By way of contrast, the number of temporary residents receiving PhDs grew considerably and the increase accounted for more than 50 percent of the growth in $\mathrm{PhD}$ production in the United States (Stephan et al. 2002). Permanent residents provided for another 10 percent. Growth of the foreign born was especially strong during the first twelve years of the period. The number of foreign-born declined somewhat during the early 1990s but increased towards the end of the 1990s.

Figure 2 documents the dramatic increase in the number of $\mathrm{PhD}$ recipients holding temporary visas during the period 1981-1992, followed by a decline during the next seven years (Black and Stephan, forthcoming). In 1981 fewer than 2,500 PhD recipients in S\&E held temporary visas (20 percent of all those receiving PhDs in S\&E); by 1992 the number stood at close to 7,000 (38.4 percent of all doctoral degrees awarded in S\&E that year). Seven years later, in 1999, the number had decreased by approximately 1,000, with temporary-visa recipients receiving approximately 32 percent of all PhDs awarded in S\&E that year. Part of the decline in the early-to-mid 1990s reflects the passage of the Chinese Student Protection Act that permitted Chinese nationals temporarily residing in the US to switch to permanent resident status. The decline is also related to a statistical artifact. Beginning in 1997, when the Survey of Earned Doctorates (SED) survey procedures were changed, a considerable increase in the number of doctorate recipients with “unknown” citizenship status occurred.

The growth in temporary residents was especially dramatic in the fields of the biological and agricultural sciences and math and computer sciences. In the former, the 
percent of temporary residents receiving PhDs more than doubled during the period 1981-1992, going from approximately 13 percent to almost 28 percent. It then fell slightly, to approximately 26 percent by 1999. In math and computer sciences the percent increased from 23.5 percent in 1981 to 46 percent in 1991. It stood at 39 percent in 1999. The change in composition has been less dramatic in engineering, but the proportion of doctorate recipients who are temporary residents in this field is substantial, hitting a high of 50.5 percent in 1991 and closing the decade at 39.6 percent.

\subsection{Recent Enrollment Trends}

The number of citizens and permanent residents enrolled as graduate students at doctoral granting institutions decreased fairly consistently from around 1992 until 2001 in engineering and the physical sciences (National Academies, 2005, pp. 22-23). Enrollment in the life sciences did not suffer a similar fate although to the extent that there was growth it was fairly minimal. During this same time period, the number of temporary residents enrolled as graduate students at doctoral granting institutions grew considerably, especially in engineering and the physical sciences.

Considerable attention has focused on declining applications and admissions of international graduate students after 9/11. For example, graduate applications across the board declined by 28\% between 2003 and 2004; admissions declined by 18\% and enrollments by 6\% (National Academies 2005, p. 31). ${ }^{7}$ What is often not noted, however, is that the benchmarks against which these enrollments are compared are unusual in the sense that the rapid rise in the mid-to-late 1990s may have been generated by unsustainable forces, such as the boom in IT jobs and the dramatic run-up in the NIH budget and the widespread availability of research assistantship funding (National Academies 2005). Moreover, factors independent of 9/11 undoubtedly contributed to the decline, including increased foreign competition for graduate students and adverse economic conditions in the U.S. in the early years of this century.

\subsection{Postdocs}

\footnotetext{
${ }^{7}$ The comparable figures for engineering are -36.0-, -24.0, -8.0; for the life sciences they are $-24.0,-19.0$ and -10.0 . For the physical sciences they are $-26.0,-17.0$, and +6.0 . Data come from the Council of Graduate Schools (National Academies, p. 31). It should be noted that application and admission data double count to the extent that students apply and are admitted to multiple programs.
} 
The number of non-physician academic postdoctoral scholars working in the U.S. in the fields of science and engineering has almost doubled since the middle of the 1970s, going from about 20,000 to 38,000 (National Academies, p. 35). Growth in the number of postdocs has been fueled in large part by scholars coming from abroad. During the period for which data by visa status is available, the number of postdoctoral scholars on temporary visas has risen from 6,472 in 1983 to 21,601 in 2002. The growth has been greatest in the life sciences. Many of these postdocs earn their PhDs in the U.S. prior to applying for a postdoctoral position, but a not insignificant number receive their $\mathrm{PhD}$ training outside the U.S. and come to the U.S. to take a post doc position. For those trained in the U.S., Stephan and Ma (2005) find temporary residents to be significantly more likely to take a post doc position than those who are citizens or permanent residents.

\section{The Role of the Foreign-Born in Innovation}

Levin and Stephan (1999) examine whether the foreign-born and foreigneducated contribute disproportionately to U.S. science by testing whether the foreignborn and foreign-educated are disproportionately represented among individuals making exceptional contributions to science and engineering (S\&E) in the United States. They argue that there are several reasons why the foreign-born may disproportionately contribute. Some of these apply specifically to graduate students; others do not. First, and depending upon immigration law in effect at the time of entry, a work permit can require an employer declaration that the scientist is especially talented. Second, given the personal sacrifices immigration requires, immigrant scientists are likely to be highly motivated. Third, foreign-born scientists and engineers who come to the U.S. to receive training, especially at the doctoral or postdoctoral level, are typically among the most able of their contemporaries. Often they have passed through several screens: they have been educated at the best institutions in their countries, withstanding intense competition for the limited number of slots available, and they have competed with the best applicants from many countries, including those from the U.S., before being selected for further training in the U.S. (Rao 1995; Bhagwati and Rao 1996). Finally, there is some evidence that suggests that the average quality of U.S.-born individuals choosing to get doctorates in S\&E declined during the 1960s, 1970s and 1980s (Stephan and Levin 1992). This was 
brought about by a phenomenal growth that occurred in Ph.D. production in the 1960s and early 1970s, which arguably diluted the talent pool in science, followed by a brain drain as bright students sought more lucrative careers in business, law and medicine. ${ }^{8}$

Levin and Stephan use six different indicators of exceptional work to test the hypothesis: individuals elected to the National Academy of Sciences (NAS) and or/National Academy of Engineering (NAE), authors of citation classics, authors of hot papers, the 250 most-cited authors, authors of highly-cited patents, and scientists who have played a key role in launching biotechnology firms. They do not claim that this list is exhaustive, merely illustrative. Data were collected in the early 1990s and represent the cumulative process of accomplishment during the preceding years.

Regardless of benchmark data or indicator, Levin and Stephan find the foreignborn to be disproportionately represented among those making exceptional contributions in the physical sciences. For example, they find that more than half (55.6\%) of the “outstanding” authors in the physical sciences are foreign-born compared to just $20.4 \%$ of physical scientists in the scientific labor force as of 1980. They also find that the foreign-educated are disproportionately represented for a number of the indicatorsamong most-cited and outstanding authors, as well as first authors of hot papers.

Recently Stephan and Levin (forthcoming) have explored whether this results would persist if more current data were to be collected, updating the study by examining the composition of the National Academy of Sciences by birth and educational origin for the year 2004. Chi-square tests indicate that the foreign-born remain disproportionately represented in all NAS sections in which they were disproportionately represented in 1994. However, the authors note that the results are based on using the 1980 benchmark of the underlying distribution of the foreign-born in U.S. science for the basis of the Chisquare tests. If instead they had chosen to use a 1990 benchmark, they would have come up with a substantially different conclusions, finding the native-born to be disproportionately represented among all members as well as members of the life science sections, and disproportionately represented (although at a lower level of significance)

\footnotetext{
${ }^{8}$ There is evidence that the decline in quality continued through the 1990s. A study sponsored by the Sloan Foundation (Best and the Brightest 2000) found that among U.S.-citizen GRE test-takers scoring 700 or above on the quantitative test the number going on to graduate school in an S\&E field declined during the period between 1987-88 and 1997-98.
} 
among members of the engineering section. In the other four fields, one cannot reject the hypothesis that the distributions are the same as the underlying population.

The authors see these findings as suggesting that the United States may be in a transition period in terms of the contribution of the foreign-born. ${ }^{9}$ It is difficult to know why. One possibility relates to a change in the underlying age distribution. The dramatic increase in the proportion foreign-born working in the U.S. is due in large part to the immigration of young scientists and engineers. These younger foreign-born scientists and engineers have a lower probability of having made exceptional contributions or, if they have, of being recognized for their contributions by 2004. Stephan and Levin do not know if their findings would change if they were to focus on different indicators of exceptional contribution, especially indicators that have a higher representation of “young” scientists and engineers than does the NAS. They do note, however, that in their earlier work (Stephan and Levin 2001b) the proportion foreign-born among first and nonfirst authors of hot papers in the life sciences was not significantly different from the proportion found for life scientists in the 1990 benchmark population. That proportion was, however, significantly different for the physical scientists. These findings are especially relevant since the hot paper indicator picks up significant work soon after it is published; thus the young need not wait until middle-age to be recognized as having made a significant contribution. When they make the tests for hot papers conditional on age, the results persist for the younger group. The benchmarks were not, however, stratified across multiple age categories and the results could change if they had more categories. $^{10}$

In somewhat related work, Lee (2004) examines whether foreign-born scientists in the U.S. perform differently than native-born scientists. He has three measures of performance: publications, grants awarded and research-collaboration. Data come from curricula vitae and survey responses conducted by the Research Value Mapping Program at the Georgia Institute of Technology. The survey was conducted from 2000 to 2001; the sample size is 443. All members of the sample were affiliated with NSF or DOE

\footnotetext{
${ }^{9}$ Stephan and Levin (forthcoming) note that the apparent transition may also be an artifact of events that transpired more than sixty years ago when events in Europe in the 1930s led a significant number of exceptional scientists to immigrate to the United States.

${ }^{10}$ The test divided the groups into those who were under 48 and those who were 48 or over at the time the papers were declared hot.
} 
centers at universities. Lee’s results show the foreign-born to publish consistently more than their native-born counterparts, controlling for field. He finds no significant difference between the foreign-born and the native-born in terms of research collaboration and grants received.

In other work, Stephan, Gurmu, Sumell and Black (forthcoming) examine the patenting activity of faculty at U.S. universities, using data from the 1995 Survey of Doctorate Recipients (SDR). The analysis controls, among other things, for whether or not the faculty member is a U.S. citizen. The authors find no evidence that patenting is related to citizenship status.

Chellaraj, Maskus and Mattoo (CMM) (2006) estimate an innovation production function in which graduate students are an input into the production of patents, both at universities and in the private sector. They use aggregate annual data for the period 1963-2001. They find the number of international graduate students to be positive and significant in both patent equations, holding constant the total number of graduate students and the cumulative number of doctorates in science and engineering. They conclude that a ten-percent increase in the number of foreign graduate students would raise patents granted to universities by $5.8 \%$ and non-university patent grants by $5.0 \%$. The policy implication of their work is clear: the decline in foreign graduate student applications and enrollments occasioned by 9/11 could affect the long run ability of the U.S. to glean the resulting economic growth brought about by innovation.

The implication that domestic and foreign graduate students are not substitutes stands in marked contrast to the work of Borjas (forthcoming), who found a strong negative correlation between the number of native men enrolled in U.S. graduate programs and the number of foreign students enrolled in these programs. Like Borjas, CMM also fail to distinguish graduate students by field of study.

Here we are able to distinguish between fields of patent activity and relate this to field of graduate training at the university level. By drilling down to the field and university level, we can more fully explore whether the CMM results are spurious or represent the differential input that the foreign-born bring to the process of innovation. ${ }^{11}$

11 In more recent work, Maskus with coauthors Stuen and Mobarak (Stuen, Mobarak, and Maskus 2006) argue that the CMM results may be biased due to the presence of unobservable factors that lead 


\section{Data and Methods}

\subsection{Data and Hypotheses}

Here we examine the question of how university patenting activity relates to human resource inputs. An issue of interest is whether all PhDs and postdocs contribute equally to patenting or whether there is a differential effect depending upon visa status. While we would like to know the citizenship status of faculty as well as doctoral students and postdocs, data limitations restrict our ability to differentiate faculty by citizenship status. We must be content with examining whether international doctoral students and postdocs contribute differentially to the production of university patents.

The dependent variable is a count of the patents awarded by year at 171 Carnegie institutions in the five broad disciplinary areas of chemicals (excluding drugs); drugs and medical; computers and communications; electrical, electronic and mechanical; and other. The period of analysis is 1985-1999. Pre-sample values from 1977-1984 are also used in constructing lags and stocks of key explanatory variables. In most instances, the data are for a campus. However, there are instances for which the data are only reported at the system level, as, for example, is the case of the University of California system. Bhaven Sampat hand-coded the university assignees from the U.S. PTO database. ${ }^{12}$

Data for the independent variables come from a variety of sources. The count of PhDs (by visa status) comes from the Survey of Earned Doctorates. The count of the number of postdoctorates come from the Survey of Graduate Students and Postdoctorates in Science and Engineering as reported on WebCASPAR, and the academic research expenditure data come from the Survey of Research and Development Expenditures at

patterns of innovation and graduate enrollment of foreign students to be systematically related. In an effort to address this question, they instrument enrollment by region of origin. Their reasoning regarding the need for instruments hinges on the argument that both patent counts and the enrollment mix of graduate students relate to the quality of the faculty, which they see as changing over time. This line of argument omits the more obvious line of reasoning that patent counts are strongly related to the culture of the university, and changes in this culture, as Owen-Smith and Powell (2001) argue so convincingly. Their results are also problematic, both in terms of their choice of instruments (fluctuations in special drawing rights, GDP per capita in source countries, a measure of oil dependence, and changes in state policies with regard to study in the United States) as well as the implementation of the instrumental variable method in a non-linear individual effects count model.

${ }^{12}$ Assignment data undercounts the numbers of patents invented by university faculty. Recent work by Thursby and Thursby (2005) shows that something like 30\% of all patents having a faculty inventor are assigned to a non-university entity. 
Universities and Colleges, also available on WebCASPAR. The variable indicating whether the university has a TTO office was collected from AUTM data. Faculty count data come from the Higher Education General Information Survey (HEGIS) and the Integrated Postsecondary Education Data System (IPEDS), as reported in WebCASPAR. ${ }^{13}$ The name of the institution was used to link the various databases. ${ }^{14}$

The variables are defined in Table 1 . Several things should be noted. First, in the case of PhDs awarded, we are able to differentiate between international students who had permanent residency at the time of the PhD and those who had temporary residency. The postdoc data does not permit this distinction; the only differentiation is between those on temporary visas and those who are either permanent residents or U.S citizens, herein after referred to at "U.S. postdocs." We should also note that some of the international respondents to the SED do not reveal their visa status (about 1.7\%) while others do not reply to the citizenship question (9.4\%). We have placed these two responses together in "other."

Patent counts by field were determined by Sampat using patent classes. ${ }^{15}$ For purposes of analysis, and to facilitate linking academic fields with patent classes, we have combined the field of electrical and electronics with the field of mechanical. A crosswalk between the SED fields, WebCASPAR fields and the five patent categories is available from the authors upon request.

Taken together, the unbalanced panel database has 11,997 observations. ${ }^{16}$ Observations are missing in instances where a field is not available at an institution (by way of example, electrical engineering at Emory University) or in instances where there is only one year of data for a given institution.

\subsection{Lags}

The amount of time that elapses between performing research and the award of a patent is non-trivial and includes both the lag between the commencement of research

\footnotetext{
${ }^{13}$ The number of faculty is unavailable for 1984 and 1987-1989. Missing values for the number of faculty for these years are imputed using historical data from 1971 to 1999 given by institution and academic field.

${ }^{14}$ In addition to these variables, we also control for year and include a variable to indicate if information were not available on the presence of a TTO office.

${ }^{15}$ These patent classes are available at http://www.uspto.gov/web/offices/opc/documents/classescombined.pdf.

${ }^{16}$ We have data on 171 institutions, for fifteen years, for five fields, making the maximum possible number of observations equal to $12,825(171 * 5 * 15)$.
} 
and the patent application as well as the lag between the patent application and awarding of the patent. The first lag is somewhere in the neighborhood of 18 months, assuming that the lag is comparable to that that occurs between the commencement of research and publication. (Stephan and Levin 1992). The latter lag is considerably longer. Murray and Stern (2005), for example, report a lag of 37.5 months on average for patents in their sample that were "paired" with a publications appearing in Nature Biology during the period 1997-1999. Popp, Juhl and Johnson ( 2004), in their in-depth study of time that elapses at the USPTO between application and award for the period 1976-1996, report a mean grant lag of 28 months across all fields and institutional types; a mean of 37.3 for patents submitted by universities. They also show that there is considerable variance across fields and over time. Lags grew in the late 1970s and early 1980s, then declined until 1990 whereupon they began to steadily increase.

Here we assume the lag to be approximately four years between the time the research is done and the patent is awarded. We thus relate the dependent variable to R\&D expenditures that are available during this time as well as to the number of faculty working at the university at this time. R\&D is measured in one of two ways. The first and preferred measure is the R\&D stock, depreciated at a 15\% rate, based on lags of 4 to 8 years; the second measure is R\&D expenditures with lags of four and five years. ${ }^{17}$ Our measure of faculty is lagged four years from the time of receipt of the patent as is the postdoc measure. The PhD variable measures the stock of PhD students at the university in year t-4 by summing the number of PhDs awarded in the first, second, third and fourth year prior to the patent being granted. Our reasoning is that $\mathrm{PhD}$ students on average take six to seven years, depending upon field, to complete their studies. This means that $\mathrm{PhDs}$ who graduates in year t-1, for example had been at the institution for 6 to 7 years prior to graduation and thus were in their third or fourth year of graduate study when the research (assuming a 4 year lag) was conducted. By summing the number of PhDs awarded over the four year period, we create a measure of the stock of $\mathrm{PhDs}$ in their most productive years working at time $\mathrm{t}-4$ at the university.

\footnotetext{
${ }^{17}$ Lags of R\&D expenditure as well as the stock of R\&D are constructed using academic R\&D expenditure which is available from 1973 onward.
} 
The distribution of the university-assigned patent counts for the 171 institutions is given in Table 2 . We see that almost $60 \%$ of the observations are zero, indicating that in six out of ten cases no patents were assigned in that year in the field delineated by institution. The table also shows that the presence of zeros declines overtime, indicating that patent activity became more widely based across fields and institutions over time. While in 1985, almost three-quarters of the observations were zero, by 1999 only 50\% were zero. Moreover, the right tail has become considerably denser overtime.

Summary statistics for the pooled data for the five fields over the period 19851999 are provided in Table 3. We see that there is tremendous variation in the number of patents issued, going from zero to 182 (University of California). We note that the data are fairly evenly split across the five fields, as is to be expected, although there are fewer observations in the field of computer and communication. The large variation in faculty size and $\mathrm{R} \& \mathrm{D}$ expenditures, as well as the postdoc and $\mathrm{PhD}$ count data, reflect in part the fact that in some instances the data are available only at the system wide level, although in most instances they are available at the campus level.

The data indicate a large presence of students and postdocs. To wit, the mean number of all $\mathrm{PhD}$ students is approximately 81; the mean for U.S. PhDs is 47; non-U.S. is 34. Approximately 24 of the non-citizens $\mathrm{PhDs}$ are temporary residents at the time they received their $\mathrm{PhD}$, while slightly more than 6 have permanent residency. (The residual fall in the "other" category.) Postdocs are even more likely to be international than are recent $\mathrm{PhD}$ recipients: the mean number of postdocs on temporary visas is slightly over 18; the mean number of postdocs who are U.S. citizens or permanent residents 19.

\subsection{Estimation Methods}

We estimate the knowledge production function using individual effects count data models. The dependent variable is the count of patents issued to the $i$-th academic institution for a given field during year $t$, denoted by patent ${ }_{i t}$. The conditional mean for patent innovation is specified as 


$$
E\left[\text { patent }_{i t} \mid \operatorname{frgnb}_{i t}, X_{i t}, v_{i}\right]=\exp \left(\operatorname{frgnb}_{i t} \gamma+X_{i t} \beta\right) v_{i},
$$

where $\operatorname{frgnb}_{i t}$ is a vector of the measures of the number of foreign-born graduate students, $X_{i t}$ is of vector of other control variables, $v_{i}$ are individual effects at the academic institution-field level, and $\gamma$ and $\beta$ are vectors of unknown parameters associated with the determinants of patenting behavior. As discussed above, the control variables include the logarithm of faculty, the stock of $\mathrm{PhD}$ students, the logarithms of academic R\&D expenditure, the number of postdocs, academic field, availability of technology transfer office, appropriately lagged, and year fixed effects. Except for academic field, the remaining explanatory variables change overtime (years).

In implementation, we use the random effects negative binomial model of Hausman, Hall and Griliches (1984), based on the maximum likelihood procedure. We choose this over the fixed effects Poisson model, which has some robustness properties for estimating the parameters in the conditional mean equation (1) that the negative binomial does not have. Our reasoning is that in applications such as ours the fixed effects Poisson estimator leads to substantial loss of data since observations for unit (institution-field) $i$ with overtime sum of number of patents equal to zero do not contribute to the estimation. ${ }^{18}$ Although the negative binomial model requires stronger assumption than Poisson, the model allows for estimation based on all observations and the effects of time-constant factors on patenting can be estimated.

The coefficient on a given logged factor (e.g., $\log \mathrm{R} \& \mathrm{D})$ in equation (1) is the elasticity of the expected number patent innovation with respect to the explanatory variable. For variables that are in level form, such as the stock of PhD students, the estimates are semi- elasticities.

\section{Empirical Results}

\subsection{Full Sample}

\footnotetext{
${ }^{18}$ In our application with 11997 observations about 25\% of the observations are dropped due to these all zero patent outcomes.
} 
Results for the negative binomial model for the full sample are presented in Table 4. ${ }^{19}$ Eleven specifications are presented. Four sets of variables deserve comment before discussing those of particular interest to this study. Specifically, the results indicate that patent counts are highly sensitive to $R \& D$ expenditures. Regardless of whether the $R \& D$ variable is included as a depreciated stock or as a lagged variable, we find a patent elasticity with regard to $R \& D$ in the neighborhood of .30. Second, the TTO variable is always positive and significant. Third, the discipline dummy variables are all negative and highly significant indicating that, other things being equal, patents are most likely to be granted in the benchmark field of chemicals. ${ }^{20}$ When we rank fields in terms of the field effect on patenting, we find that patents are highest in chemicals, followed by drugs and medical, with computer and communications and electrical, electronic and mechanical being tied for third place and “other” being last. Finally, the variable that indicates whether the university is a top 110 U.S.-institution, as measured by ISI in terms of publication counts ${ }^{21}$ (and referred to here as "Science Watch" institutions) is always positive and highly significant.

We divide university researchers into three categories: faculty, postdoctoral scholars and PhD students. Specification (1) includes only faculty. The coefficient is highly significant with an elasticity of .06. Specification (2) adds the number of postdoctoral scholars to the estimate of the production function; the variable is positive and highly significant. Specification (3) replaces the stock of PhDs for the stock of postdoctoral scholars; the coefficient on the variable is again positive and highly significant. Specification (4) includes measures of the three categories of university researchers. We find all three measures of researchers to be positively and significantly related to the number of patents awarded with an elasticity of around .04 for faculty and a

\footnotetext{
${ }^{19}$ The Akaike information criteria (AIC) and Bayesian information criteria (BIC) were used in selecting the preferred models.

${ }^{20}$ We test to see if differences in patenting exist between fields and find for all institutions that we can reject the hypothesis at the $1 \%$ level that the coefficients are the same on the field variables in favor of the alternative hypothesis that they are different for all combinations of field differences. The exception is the difference between drugs and medical and electrical, electronic and mechanical, which is significant at the $5 \%$ level, and the difference between computer and communications and electrical, electronics and mechanical which is not significantly different at a test value of less than $10 \%$.

${ }^{21}$ ISI analyzes publication counts in Science Watch for the top 110 publishing universities in the U.S.
} 
semi-log elasticity of around .04 for PhDs and postdocs. The significance of the coefficient on the log of faculty, however, falls to 10 percent.

One issue of interest to us is whether the contribution of $\mathrm{PhDs}$ and posdocs depends upon visa status. This is examined in specifications 6-10. The results suggest that not all PhDs and postdocs contribute equally to the production of patents. Specifically, and regardless of specification, patents are positively and significantly related to the number of postdocs on temporary visas; there is no support for the hypothesis that the number of US postdocs (which, in the case of this measure, includes postdocs with permanent residency) contribute significantly to patenting activity. Using a Wald Test, we explore whether the coefficients on the postdoc variables are significantly different from each other and find that we can reject the null hypothesis that the coefficients are the same at the $1 \%$ level of significance. ${ }^{22}$

The results suggest that programs with large numbers of international postdoctorates on temporary visas produce more patents than do programs with large numbers of citizens and permanent resident postdocs, other things being equal. This is a curious result and we are not quite sure what to make of it. One possible explanation relates to measurement error. The one human resource component which we have not been able to measure constitutes the more or less permanent staff scientists who work in labs. Retaining and hiring such scientists clearly requires resources and commitments to programs. It is possible that programs which cannot hire such staff scientists hire postdocs in their stead, primarily postdocs on temporary visas, who often receive lower compensation than do U.S. citizen postdocs.

Specifications 7 to 10 explore whether the results are sensitive to the visa status of PhD students. When we differentiate by visa status we find patents to be positively and significantly related to the number of U.S.-citizen $\mathrm{PhD}$ students but find the variable that measures the stock of international PhDs to be insignificant. In specification 8 we group permanent resident PhDs with U.S. PhDs and include additional variables to measure the number of temporary resident-PhDs and “other-PhDs” as measures of human capital inputs. The result is stunning in the sense that the coefficient on the temporary PhD

\footnotetext{
${ }^{22}$ A Wald test indicates that the two variables are also jointly significant at the $1 \%$ level. Tests are based on specification 10 .
} 
variable is negative and significant at the $5 \%$ level; the coefficient on the citizen and permanent resident variable is positive and significant at the $1 \%$ level. Specification 9 repeats this exercise, but includes the postdoc measures. The results persist although the size of the coefficient on the U.S and permanent resident $\mathrm{PhD}$ measure declines. In specification 10, we differentiate the stock of permanent resident PhDs from that of U.S. PhDs. The results are fairly consistent with what we found earlier: Patents are positively and significantly related to international postdocs and U.S. PhDs. They are negatively and significantly related to the stock of PhDs on temporary visas. A Wald test to see if the coefficients on the U.S. PhD variable is significantly different from that on the temporary $\mathrm{PhD}$ variable is significant at the $1 \%$ level, indicating that we can reject the hypothesis that the coefficients are equal; we cannot reject the hypothesis that the coefficients on the permanent $\mathrm{PhD}$ variable and temporary variable are equal; neither can we reject the hypothesis that the coefficients on the U.S. PhD variable and the permanent $\mathrm{PhD}$ variable are significantly different at conventional levels of significance. ${ }^{23} \mathrm{~A}$ headline here is that temporary residents are different from citizen PhDs. The results persist when the log of lagged $R \& D$ expenditures is substituted for the stock of $R \& D$ expenditures (specification 11).

Our results clearly indicate the importance of distinguishing between the number of citizen-PhD students and temporary-resident PhDs and suggests that not all graduate students contribute equally to patenting. One reason temporary residents may not contribute to the patenting process is that they may lack the language and cultural skills that make for high productivity in the lab. Our research suggests that there is some truth to this. Using the SED, we find that among the 93,689 temporary residents who received their PhDs in science and engineering in the United States during the period 1981-1999, only .33\% attended high school in the U.S. and 6.59\% received their baccalaureate degree in the U.S. By way of contrast, $15.52 \%$ of the permanent residents who received

\footnotetext{
${ }^{23}$ The coefficients on U.S. PhDs, temporary PhDs and permanent PhDs are jointly significant at the $1 \%$ level.
} 
their PhDs in the U.S. in science and engineering during the period got their undergraduate degree in the U.S. and 5.36\% went to high school in the U.S. also. ${ }^{24}$

Another possible reason why the results are sensitive to the composition of $\mathrm{PhDs}$ studying in a program may relate to the selectivity of the program, with the argument that top programs are able to select highly productive students regardless of visa status and that lower rated programs often fill their $\mathrm{PhD}$ classes by admitting students, many of whom are on temporary visas, who could not gain admission to top programs. We repeat the analysis focusing on "top" institutions, using three different measures of quality: top 110, top 25 and top 10. The broadest category is defined by institutions included in Science Watch. The top 25 and top 10 institutions are defined to be those in which at least one of the four programs is rated a top 25 or a top $10,{ }^{25}$ either by the 1993 National Research Council Report, or, in the case of departments in medical schools, by their rank according to size of federal R\&D support in $1998 .^{26}$

\subsection{Results by selectivity of $\mathrm{PhD}$ program}

Specifications 4 and 10 are presented in table 5 for "top" institutions. Other specifications are available from the authors. The results for the top, regardless of definition, are not that different than the results obtained when all institutions are analyzed together. The elasticity with respect to the stock of R\&D is larger, however. The signs and significance of the human resource input variables remain approximately the same: faculty are positively and significantly related to patents for "top 110 " institutions;, postdocs and $\mathrm{PhDs}$ are positively and significantly related to patents regardless of institutional classification. When the variables are differentiated by visa status we find similar results to those found for all 171 institutions. The variable measuring postdocs on temporary visas is positively and significantly related to patent counts; citizen and permanent resident posdocs are not. The coefficients on the two variables are significantly different at the $1 \%$ level using a Wald test regardless of definition of top.

\footnotetext{
${ }^{24}$ We also find that $31 \%$ percent of the "other" visa status group received their undergraduate degree in the U.S. and $16 \%$ did not indicate where they received their degree. Almost all the others received their degrees outside the U.S.; a very small percent did not receive an undergraduate degree.

${ }^{25}$ Since the criteria is "one or more programs" the number of institutions classified as top 25 or top 10 exceeds 25 and 10 respectively.

${ }^{26}$ The NRC rankings are not available for medicine.
} 
The stock of U.S. PhDs is again positive and significant, the stock of permanent resident $\mathrm{PhDs}$ is not significant and the stock of temporary resident $\mathrm{PhDs}$ is negative and significant. The estimated effect of U.S. PhDs vs. temporary PhDs on the production of patents is significantly different at the $1 \%$ level. The results suggest that differential program quality does not explain why $\mathrm{PhD}$ programs with more $\mathrm{PhDs}$ students on temporary visas generate fewer patents.

\subsection{Estimates by Discipline}

To investigate the degree to which the results vary by discipline, we re-estimate the model for each of the fields. The results are presented in the appendix. Table A1 presents descriptive statistics for all institutions in the sample by field; table A2 presents descriptive statistics for institutions having at least one top-25 rated program. We see that there is wide variation across programs in terms of the average number of postdocs and PhD students. The mean program in drugs and medical devices at a campus has 122 postdocs while that in computers and communication has a mere 1.2. In between fall chemicals (24) and electrical, electronics and mechanical at 21.3. The spread is narrower for the stock of PhDs. Here we find that the largest stock is in electrical and electronics (121); the smallest stock in computers and communications (21.5).

The results for specification 10 are presented in Table A3; results which control for whether an institution is a top 25 are presented in Table A4. The stock of R\&D expenditures is always positive and highly significant across the four disciplinary areas for both samples but the elasticities vary considerably by field. For example, the elasticities for electrical, electronics and mechanical, as well as that for drugs and medical, are nearly twice as large as that for chemicals and computer and communications. The faculty variable is only significant for electrical, electronics and mechanical in specification 4.

Our finding that the stock of U.S. PhDs is positively related to patent counts is robust at the field level. In each instance the variable is positive and significant, although the semi-elasticities vary considerably, being largest in computers and communications. So, too, is our finding that we cannot reject the hypothesis that patents are not related to the number of U.S postdocs. 
Another result that is robust is that the stock of U.S. PhDs has a differential effect on patenting than does the stock of PhDs on temporary visas. In all fields and regardless of selectivity, we can reject the hypothesis that the coefficients on the U.S. and temporary PhD stock variables are equal. For drugs and medical as well as chemical, this is at the $1 \%$ level; for electrical, electronics and mechanical, it is at the $5 \%$ level. In the case of computers and communication it is at the $10 \%$ level. $^{27}$

By way of contrast, the relationship between postdocs on temporary visas and patent counts appears to be field specific. Temporary-resident postdocs are a significant input into patenting in chemicals and electrical, electronics and mechanical. But, the relationship between the stock of international postdocs and patents is negative (and significant at the 10\% level) in the field of computers and communication. Moreover, while we can reject the hypothesis that the coefficients on the two postdoc variables are identical when we estimate the fields jointly, we can no longer reject the hypothesis when the equations are estimated separately by field. The exception being that in chemicals the coefficients are significantly different at the $1 \%$ level.

\section{Conclusion}

Here we estimate a knowledge production function for university patenting during the period 1985-1999. The analysis focuses on the number of patents issued in one of five fields in time period $t$ at university $x$. A key input in the patenting process, and one that we pay particular attention to in this work, are the researchers who staff university laboratories, contributing their human capital to the innovation process. We are able to measure three kinds of researchers: faculty, postdoctoral students and $\mathrm{PhD}$ graduate students. One issue of interest to us is whether all $\mathrm{PhDs}$ and postdoctoral scholars contribute equally to patent activity or whether there is a differential effect depending upon visa status. This is a question of considerable concern given recent changes in immigration policy following 9/11, increased competition for graduate students outside the U.S. and the general lack of interest shown among U.S. citizens in pursuing $\mathrm{PhD}$ training in the sciences.

\footnotetext{
${ }^{27}$ Note that the coefficient on temporary resident is negative in each specification, regardless of selectivity. However, only in the field of chemicals is it negative and significant.
} 
We find that patent output relates positively and significantly to the stock of R\&D expenditures and the presence of a TTO office. The R\&D expenditure elasticity is around .30. We find the human resource variables to be positive and significant: patent counts relate positively and significantly to the number of faculty, number of $\mathrm{PhD}$ students and number of postdocs. The elasticity of patents with respect to faculty is 0.04 . The semi-elasticity with regard to all postdocs is 0.05 and .035 for the stock of Ph.Ds. These results are fairly robust when we limit our analysis to top programs, although the coefficient on faculty becomes fragile when we drill down to a smaller number of elite programs.

When we differentiate among PhD students according to visa status, our results suggest that not all graduate students contribute equally to patenting. There is a positive and significant relationship between patenting and citizen-PhD students and a negative and significant relationship between temporary-resident $\mathrm{PhD}$ students and patenting. The coefficients on the two variables differ significantly from each other using traditional levels of significance. The result persists when we focus on top-rated departments, suggesting that the temporary-resident variable is not a proxy for quality. For perhaps cultural reasons and quality of training PhD students on temporary visas appear to adversely affect the technology transfer process.

On the other hand, there is a clear and strong relationship between patents and the number of postdoctoral students on temporary visas. We find no such relationship between citizen and permanent resident postdocs and patenting. We are at a loss to explain this finding. One possibility, as we note in the text, relates to measurement error and our inability to count the number of permanent staff scientists working in the lab.

In a recent paper, Chellaraj, Maskus and Matto (2006) examine the relationship between the number of international graduate students and patenting. They find patent counts to be positively and significantly related to the number of international PhDs and negatively but not significantly related to the number of U.S. PhDs. Our findings, call their results into question on two counts. First, we find the number of patents to be positively and significantly related to the number of U.S. PhDs. Second, we find that placing all international graduate students into one category masks the underlying relationship. To wit: we find no significant relationship between the number of 
permanent residents and patent counts but a negative and significant relationship between the number of temporary residents receiving their $\mathrm{PhD}$ in departments working in this technology area at the university. Our results invite further research. But they suggest that care must be taken in jumping to the policy conclusion that the U.S.'s ability to innovate, at least in universities, depends upon its ability to attract international graduate students.

\section{References}

"Best and brightest avoiding science," 2000, Science, 288, 7 April, p. 43.

Bhagwati, J. \& Rao, M. 1996. Wall Street Journal 31 August.

Black, G. C. and P. Stephan, forthcoming. "The Importance of Foreign PhD Students to US Science," in Science and the University, edited by Ronald Ehrenberg and Paula Stephan, Madison, University of Wisconsin Press.

Borjas, G., forthcoming. "Do Foreign Students Crowd Out Native Students From Graduate Programs?” in Science and the University, edited by Ronald Ehrenberg and Paula Stephan, Madison, University of Wisconsin Press.

Cannon, P. 1988. Foreign Engineers in U.S. Industry: An exploratory Assessment, pp. 105-124) in Foreign and Foreign-born Engineers in the United States: Infusing Talent, Raising Issues, ed. National Research Council. Washington DC: National Academy Press.

Chang, T. 2006. Unpublished data concerning nanotechnology centers.

Chellaraj, G., K. E. Maskus, and A. Mattoo 2006 “The Contribution of Skilled Immigration and International Graduate Students to U.S. Innovation”, University of Colorado Working Paper, March.

Choi, H. 1995. An International Scientific Community: Asian Scholars in the United States. Praeger: Westport:CO.

Garger, P. 1988. "When Language Hurts Scientists and Their Employees,” The Scientist 2(15), 19, August 08.

Griliches, Z. 1979. "Issues in Assessing the Contribution of Research and Development to Productivity Growth.” The Bell Journal of Economics, vol. 10, no. 1, pp. 92-116.

Hausman, J. A., B.H. Hall, and Z. Griliches (1984). “Econometric Models for Count Data with an Application to the Patents-R\&D Relationship," Econometrica, 52, 909-938. 
Lee, Sooho (2004. Foreign-Born Scientists in the United States-Do they Perform Differently Then Native-Born Scientists? Unpublished dissertation, Georgia Institute of Technology, November 2004.

Levin, S. and P. Stephan. 1999. Are the Foreign Born a Source of Strength for U.S. Science? Science, 285, 20 August, 1213-1214.

Mowery, D. C., R.R. Nelson, B. N. Sampat, and A. Z. Ziedonis, 2004. Ivory Tower and Industrial Innovation: University-Industry Technology Transfer Before and After the Bayh-Dole Act. Stanford Business Books, an imprint of Stanford University Press: Stanford, CA.

Murray, F. and S. Stern. 2005. “Do Formal Intellectual Property Rights Limit the free Flow of Scientific Knowledge: An Empirical Test of the Anti-Commons Hypothesis? NBER working paper, number 11465.

National Academies. 2005. Policy Implications of International graduate Students and Postdoctoral Scholars in the United States, Committee on Policy Implications of International Graduate Students and Postdoctoral Scholars in the United States, Committee on Science, Engineering and Public Policy, The National Academies Press. Washington, D.C.

National. Science Board 2004. Science and Engineering Indicators 2004, National Science Foundation, Arlington, VA.

National. Science Board 2006. Science and Engineering Indicators 2006, National Science Foundation, Arlington, VA.

North, D. S. 1995. Soothing the Establishment: The Impact of Foreign-born Scientists and Engineers on America. University Press of America.

Owen-Smith, J. and W. W. Powell. 2001 “To Patent or Not: Faculty Decisions and Institutional Success at Technology Transfer,” Journal of Technology Transfer 26(1/2):99-114.

Penning, T. 1998. “The Postdoctoral Experience: An Associate Dean’s Perspective,” The Scientist, vol. 12, no. 9, 28 September.

Popp, D., T. Juhl, D. K. N. Johnson, 2004. “Time in Purgatory: Determinants of the Grant Lag for U.S. Patent Applications.” Topics of Economic Analysis and Policy, vol 4, no. 1.

Rao, M. (1995), Foreign students and graduate economic education in the United States, Journal of Economic Education 26, 274-281. 
Science 1998. “The Biocomplex World of Rita Colwell,” vol. 281, pp. 1944-1947, 25

September.

Stephan, P. E., Black, G., Adams, J. \& Levin, S. (2002), Survey of foreign recipients of U.S. Ph.D.s, Science Vol. 295, 22 March 2002, pp. 2211-2212.

Stephan, P. E., S. Gurmu, A.J. Sumell and G.C. Black, forthcoming. "Who’s Patenting in the University?” Economics of Innovation and New Technology.

Stephan, P. \& Levin, S. G. (1992), Striking the mother lode in science: The Importance of Age, Place, and Time. New York: Oxford U. Press, 1992.

2001a. "Career Stages, Benchmarking and Collective Research."

International Journal of Technology Management, vol. 22, no. 7/8, pp. 676-687.

. 2001b. Exceptional contributions to US science by the foreign-born and

foreign-educated. Population Research and Policy Review, 20,

59-79.

Stephan, P. and S. Levin, forthcoming. "Foreign Scholars in U.S. Science: Contributions and Costs," in Science and the University, edited by Ronald Ehrenberg and Paula Stephan, Madison, University of Wisconsin Press.

Stephan, P. and J. Ma. 2005. "The Increased Frequency and Duration of the Postdoctorate Career Stage, American Economic Review Papers and Proceedings, 95:7175.

Stuen, E. T., A. M. Mobarak and K. E. Maskus, 2006, Foreign Graduate Students and Knowledge Creation at U.S. Universities: Evidence from Enrollment Fluctuations.” Presented at NBER Summer Institute, meetings on Innovation Policy and the Economy, July 2006.

Thursby, J. and M. Thursby 2005. "Faculty Patent Activity and Assignment Patterns," presented at the 2005 REER meetings, Georgia Institute of Technology. 
Table 1. Description of Variables

\begin{tabular}{|l|l|}
\hline \multicolumn{1}{|c|}{ Variable Name } & \multicolumn{1}{c|}{ Variable Description } \\
\hline Patents Issued & Number of patent issued with an institution as an assignee \\
\hline Chemical Field & $\begin{array}{l}1 \text { if academic field is in chemical engineering or chemistry } \\
\text { (excluding drugs) }\end{array}$ \\
\hline Computer \& Communications & 1 if academic field is in computers and communications \\
\hline Drugs and Medical & 1 if academic field is in biological sciences or medical sciences \\
\hline Electrical, Electronic \& Mechanical & $\begin{array}{l}1 \text { if academic field is in engineering or physics (excluding } \\
\text { chemical engineering) }\end{array}$ \\
\hline Other Field & 1 if academic field is in all remaining fields \\
\hline R \& D Expenditure & $\begin{array}{l}\text { Total academic R\&D expenditure in 1000s of constant 2000 } \\
\text { dollars }\end{array}$ \\
\hline Stock of R\&D Expenditure & $\begin{array}{l}\text { Lagged stock of R\&D expenditure over the previous four to eight } \\
\text { years with depreciation of 15\% per year }\end{array}$ \\
\hline Faculty & Number of faculty at the institution \\
\hline US Postdocs & $\begin{array}{l}\text { Number of postdocs that are US citizens (with medical and non- } \\
\text { medical degrees) }\end{array}$ \\
\hline International Postdocs & $\begin{array}{l}\text { Number of international postdocs (with medical and non-medical } \\
\text { degrees) }\end{array}$ \\
\hline Stock of US PhDs & $\begin{array}{l}\text { Lagged stock of the number of PhDs awarded to US citizens over } \\
\text { the previous four years }\end{array}$ \\
\hline Stock of International PhDs & $\begin{array}{l}\text { Lagged stock of the total number of PhDs awarded to non- US } \\
\text { citizens over the previous four years }\end{array}$ \\
\hline \multicolumn{1}{|c|}{$\begin{array}{l}\text { Stock of Permanent Resident } \\
\text { PhDs }\end{array}$} & $\begin{array}{l}\text { Lagged stock of the number of PhDs awarded to permanent } \\
\text { residents over the previous four years }\end{array}$ \\
\hline Stock of Temporary Resident \\
PhDs & $\begin{array}{l}\text { Lagged stock of the number of PhDs awarded to temporary } \\
\text { residents over the previous four years }\end{array}$ \\
\hline Stock of Other PhDs & $\begin{array}{l}\text { Lagged stock of the number of PhDs awarded to others - } \\
\text { unknown citizenship or visa status unknown - over the previous } \\
\text { four years }\end{array}$ \\
\hline Technology Transfer Office & $\begin{array}{l}1 \text { if institution has technology transfer office } \\
\text { rankings }\end{array}$ \\
\hline Top 110 Institution & 1 if institution is ranked in the top 25 in at least one of the fields \\
\hline Top 25 Institution & if institution is ranked in the top 10 in at least one of the fields \\
\hline Top 10 Institution & of one of the top 110 institutions by NRC \\
\hline
\end{tabular}


Table 2. Percentage Distribution of Patents Issued to Universities by Rankings for all Fields (1985 - 1999)

\begin{tabular}{|c|c|c|c|c|c|c|c|c|}
\hline & \multicolumn{5}{|c|}{ All Institutions } & Top & Top & Top \\
\hline Number of & $1985-$ & 1985 & 1990 & 1995 & 1999 & 1985- & 1985- & 1985- \\
\hline Patents & 1999 & & & & & 1999 & 1999 & 1999 \\
\hline 0 & 59.9 & 73.7 & 61.9 & 53.4 & 50.0 & 42.6 & 36.0 & 25.9 \\
\hline 1 & 14.1 & 14.7 & 14.6 & 16.6 & 14.4 & 17.3 & 16.1 & 15.3 \\
\hline 2 & 7.7 & 5.1 & 7.9 & 10.1 & 7.3 & 10.6 & 11.2 & 11.4 \\
\hline 3 & 4.7 & 1.9 & 4.8 & 6.1 & 3.8 & 7.0 & 8.1 & 9.3 \\
\hline 4 & 3.1 & 1.2 & 3.3 & 3.2 & 3.9 & 4.9 & 5.8 & 6.9 \\
\hline 5 & 2.1 & 0.6 & 1.8 & 2.2 & 2.5 & 3.2 & 3.9 & 4.8 \\
\hline $6-10$ & 4.8 & 2.2 & 3.5 & 6.0 & 9.5 & 8.0 & 10.2 & 12.7 \\
\hline $11-182$ & 3.7 & 0.5 & 2.4 & 4.5 & 8.7 & 6.4 & 8.8 & 13.8 \\
\hline Total (\%) & 100 & 100 & 100 & 100 & 100 & 100 & 100 & 100 \\
\hline Total (observations) & 11997 & 780 & 797 & 806 & 814 & 6837 & 4703 & 2471 \\
\hline
\end{tabular}


Table 3. Means (Standard Deviations) For Academic Institutions for all Fields By Academic Rankings (1985 - 1999)

\begin{tabular}{|c|c|c|c|c|}
\hline \multirow[t]{2}{*}{ Variable } & \multirow{2}{*}{$\begin{array}{c}\text { All } \\
\text { Institutions }\end{array}$} & \multicolumn{2}{|c|}{ Top Programs } & \multirow[b]{2}{*}{ Top 10} \\
\hline & & Top 110 & Top 25 & \\
\hline \multirow[t]{2}{*}{ Patents Issued } & 1.855 & 3.004 & 3.841 & 5.512 \\
\hline & $(5.65)$ & (7.23) & $(8.42)$ & $(10.88)$ \\
\hline \multirow[t]{2}{*}{ Chemical Field } & 0.208 & 0.202 & 0.201 & 0.201 \\
\hline & $(0.41)$ & $(0.40)$ & $(0.40)$ & $(0.40)$ \\
\hline \multirow[t]{2}{*}{ Computer \& Communications } & 0.175 & 0.191 & 0.197 & 0.199 \\
\hline & $(0.38)$ & $(0.39)$ & $(0.40)$ & $(0.40)$ \\
\hline \multirow[t]{2}{*}{ Drugs and Medical } & 0.206 & 0.204 & 0.201 & 0.200 \\
\hline & $(0.40)$ & $(0.40)$ & $(0.40)$ & $(0.40)$ \\
\hline \multirow[t]{2}{*}{ Electrical, Electronic \& Mechanical } & 0.201 & 0.199 & 0.200 & 0.200 \\
\hline & $(0.40)$ & $(0.40)$ & $(0.40)$ & $(0.40)$ \\
\hline \multirow[t]{2}{*}{ Other Field } & 0.210 & 0.204 & 0.201 & 0.200 \\
\hline & $(0.41)$ & $(0.40)$ & $(0.40)$ & $(0.40)$ \\
\hline \multirow[t]{2}{*}{ Stock of R\&D Expenditure } & 65833.658 & 104101.800 & 125717.300 & 174781.400 \\
\hline & (156771.90) & (198051.10) & $(230630.60)$ & (295631.30) \\
\hline \multirow[t]{2}{*}{ R\&D Expenditure } & 23175.027 & 36650.075 & 44379.462 & 60729.55 \\
\hline & (55221.36) & (69791.31) & $(81440.46)$ & $(104489.3)$ \\
\hline \multirow[t]{2}{*}{ Faculty } & 1111.487 & 1370.235 & 1536.26 & 1579.567 \\
\hline & $(967.53)$ & $(1167.36)$ & $(1338.89)$ & $(1421.84)$ \\
\hline \multirow[t]{2}{*}{ All Postdocs } & 37.040 & 61.114 & 78.18 & 111.787 \\
\hline & $(146.92)$ & $(190.93)$ & $(226.36)$ & $(302.06)$ \\
\hline \multirow[t]{2}{*}{ US Postdocs - Total: } & 18.797 & 31.434 & 40.459 & 58.238 \\
\hline & $(81.84)$ & $(106.6)$ & $(126.7)$ & (169.07) \\
\hline \multirow[t]{2}{*}{ Medical US Postdocs } & 3.888 & 6.711 & 8.976 & 14.142 \\
\hline & (27.54) & (36.21) & $(43.21)$ & $(57.87)$ \\
\hline \multirow[t]{2}{*}{ Non-Medical US Postdocs } & 14.909 & 24.724 & 31.483 & 44.1 \\
\hline & (56.51) & (73.24) & (86.79) & $(115.17)$ \\
\hline \multirow[t]{2}{*}{ International Postdocs -Total: } & 18.242 & 29.679 & 37.72 & 53.55 \\
\hline & $(67.54)$ & (87.57) & $(103.4)$ & $(137.60)$ \\
\hline \multirow[t]{2}{*}{ Medical International Postdocs } & 3.353 & 5.7 & 7.412 & 11.885 \\
\hline & $(23.39)$ & $(30.75)$ & $(36.56)$ & $(49.42)$ \\
\hline \multirow[t]{2}{*}{ Non-medical International Postdocs } & 14.890 & 23.979 & 30.308 & 41.664 \\
\hline & $(46.83)$ & $(60.25)$ & $(70.81)$ & $(93.30)$ \\
\hline \multirow[t]{2}{*}{ Stock of All PhDs } & 80.705 & 123.669 & 153.547 & 198.575 \\
\hline & $(142.96)$ & $(175.78)$ & $(201.49)$ & $(255.17)$ \\
\hline \multirow[t]{2}{*}{ Stock of US PhDs } & 46.945 & 73.115 & 90.836 & 119.166 \\
\hline & $(90.24)$ & (111.89) & (128.99) & $(164.92)$ \\
\hline \multirow[t]{2}{*}{ Stock of International PhDs -Total: } & 33.756 & 50.554 & 62.711 & 79.409 \\
\hline & $(61.75)$ & $(76.24)$ & $(87.35)$ & $(107.90)$ \\
\hline Stock of Permanent Resident PhDs & 6.264 & 9.275 & 11.478 & 14.192 \\
\hline & (12.66) & (15.83) & $(18.25)$ & $(22.44)$ \\
\hline Stock of Temporary Resident PhDs & 24.364 & 36.386 & 44.972 & 55.217 \\
\hline & $(44.79)$ & $(55.17)$ & (63.18) & (76.92) \\
\hline Stock of Other PhDs & 3.128 & 4.893 & 6.261 & 10.000 \\
\hline & $(11.87)$ & $(15.37)$ & $(18.04)$ & $(23.96)$ \\
\hline Technology Transfer Office & 0.526 & 0.734 & 0.749 & 0.786 \\
\hline
\end{tabular}




\begin{tabular}{|l|r|r|r|r|}
\hline & $(0.5)$ & $(0.44)$ & $(0.43)$ & $(0.41)$ \\
\hline Top 110 Institution & 0.57 & & & \\
\hline & $(0.50)$ & & & \\
\hline Top 25 Institution & 0.392 & & & \\
\hline & $(0.49)$ & & & \\
\hline Top 10 Institution & 0.206 & & & \\
\hline & $(0.40)$ & & & \\
\hline Sample Size & 11997 & 6837 & 4703 & 2471 \\
\hline Number of Institution-field programs & 819 & 459 & 315 & 165 \\
\hline Number of Institutions & 171 & 93 & 63 & 33 \\
\hline
\end{tabular}


Table 4. Estimation Results from Individual Effects Model for all Institutions and Fields (1985-1999) Dependent Variable: Patent Issued to Academic Institutions in all Fields

\begin{tabular}{|c|c|c|c|c|c|}
\hline \multirow[t]{2}{*}{ Variable } & \multicolumn{3}{|c|}{ Coefficient Estimate (t-ratio) } & \multirow[b]{2}{*}{ Spec 4} & \multirow[b]{2}{*}{ Spec 5} \\
\hline & Spec 1 & Spec 2 & Spec 3 & & \\
\hline \multirow[t]{2}{*}{ Computer \& Communications } & $-0.9687^{\star \star \star}$ & $-0.962^{\star \star \star}$ & $-0.9447^{\star \star \star}$ & $-0.9545^{\star \star \star}$ & $-0.9321^{\star \star \star}$ \\
\hline & $(8.12)$ & $(8.11)$ & $(8.08)$ & $(8.1)$ & $(7.90)$ \\
\hline \multirow{2}{*}{ Drugs \& Medical } & $-0.4841^{\star \star \star}$ & $-0.5104^{\star \star \star}$ & $-0.4466^{\star \star \star}$ & $-0.494^{\star \star \star}$ & $-0.4935^{\star \star \star}$ \\
\hline & $(4.36)$ & $(4.6)$ & $(4.08)$ & $(4.47)$ & $(4.51)$ \\
\hline \multirow[t]{2}{*}{$\begin{array}{l}\text { Electrical, Electronic \& } \\
\text { Mechanical }\end{array}$} & $-0.8216^{* * *}$ & $-0.7998 * \star \star$ & $-0.8868^{\star * \star}$ & $-0.8258^{* * *}$ & $-0.8224^{\star \star *}$ \\
\hline & $(7.62)$ & $(7.42)$ & (8.35) & $(7.66)$ & $(7.69)$ \\
\hline \multirow[t]{2}{*}{ Other Field } & $-1.6222^{\star * *}$ & $-1.6074^{\star \star \star}$ & $-1.6194 * \star \star$ & $-1.6083^{\star * *}$ & $-1.6046^{\star * *}$ \\
\hline & $(13.38)$ & $(13.32)$ & $(13.58)$ & $(13.41)$ & $(13.50)$ \\
\hline \multirow[t]{2}{*}{ Log Stock of R\&D Expenditure } & $0.3323^{\star \star \star}$ & $0.3223^{\star \star \star}$ & $0.2943^{\star \star \star}$ & $0.3077^{\star \star \star}$ & \\
\hline & $(12.94)$ & $(12.48)$ & (11.15) & $(11.53)$ & \\
\hline \multirow[t]{2}{*}{ Log R\&D Expenditure_4 } & & & & & $0.2356^{\star * *}$ \\
\hline & & & & & (5.58) \\
\hline \multirow[t]{2}{*}{ Log R\&D Expenditure_5 } & & & & & $0.0698^{*}$ \\
\hline & & & & & $(1.70)$ \\
\hline \multirow[t]{2}{*}{ Log Faculty_4 } & $0.0641^{\star \star \star}$ & $0.0477^{* *}$ & $0.0534^{\star *}$ & $0.0443^{\star}$ & $0.0424^{*}$ \\
\hline & $(2.64)$ & $(2.04)$ & $(2.34)$ & $(1.92)$ & $(1.84)$ \\
\hline \multirow[t]{2}{*}{ All Postdocs_4 } & & $0.0604^{\star \star *}$ & & $0.0495^{\star \star \star}$ & $0.0487^{* \star *}$ \\
\hline & & $(9.39)$ & & $(6.07)$ & (5.98) \\
\hline \multirow[t]{2}{*}{ Stock of All PhDs } & & & $0.0853^{\star \star \star}$ & $0.0345^{\star \star}$ & $0.0365^{\star \star \star}$ \\
\hline & & & $(6.17)$ & $(2.08)$ & $(2.22)$ \\
\hline \multirow[t]{2}{*}{ Technology Transfer Office_4 } & $0.2035^{\star \star \star}$ & $0.2171^{\star \star \star}$ & $0.1936 * \star \star$ & $0.2132^{\star \star \star}$ & $0.2083^{\star \star \star}$ \\
\hline & $(5.66)$ & $(6.09)$ & $(5.46)$ & $(5.98)$ & $(5.85)$ \\
\hline \multirow[t]{2}{*}{ Top 110 Institution } & $0.8157^{\star \star \star}$ & $0.811^{\star * *}$ & $0.7887^{\star \star \star}$ & $0.8018^{\star \star \star}$ & $0.7898^{\star \star \star}$ \\
\hline & $(8.69)$ & (8.69) & $(8.61)$ & $(8.67)$ & (8.59) \\
\hline Minus log-likelihood & 13502 & 13471 & 13487 & 13469 & 13457 \\
\hline AIC & 27055 & 26996 & 27028 & 26994 & 26973 \\
\hline $\mathrm{BIC}$ & 27248 & 27195 & 27228 & 27200 & 27187 \\
\hline
\end{tabular}

Notes:
(a) Absolute value of t statistics within parentheses.
(b) *, ${ }^{* *}$ and $* * *$ indicate statistical significance at $10 \%, 5 \%$, and $1 \%$ respectively.
(c) All specifications control for year effects.
(d) Results for postdoc and PhD variables are expressed in 100s. 
Table 4 Continued)

\begin{tabular}{|c|c|c|c|c|c|c|}
\hline \multirow[t]{2}{*}{ Variable } & \multicolumn{6}{|c|}{ Coefficient Estimate (t-ratio) } \\
\hline & Spec 6 & Spec 7 & Spec 8 & Spec 9 & Spec 10 & Spec 11 \\
\hline \multirow[t]{2}{*}{$\begin{array}{l}\text { Computer \& } \\
\text { Communications }\end{array}$} & $-0.9607^{\star \star \star}$ & $-0.9408^{\star \star \star}$ & $-0.9440^{\star \star \star}$ & $-0.9474^{\star \star \star}$ & $-0.9428^{\star \star \star}$ & $-0.9204^{\star \star \star}$ \\
\hline & $(8.09)$ & $(8.02)$ & (8.03) & $(8.02)$ & $(7.98)$ & $(7.79)$ \\
\hline \multirow[t]{2}{*}{ Drugs \& Medical } & $-0.5009^{\star \star \star}$ & $-0.4681^{\star \star \star}$ & $-0.4952^{\star \star \star}$ & $-0.5108^{\star \star \star}$ & $-0.5081^{\star \star *}$ & $-0.5068^{\star \star \star}$ \\
\hline & $(4.5)$ & $(4.23)$ & $(4.47)$ & $(4.59)$ & $(4.56)$ & $(4.6)$ \\
\hline \multirow{2}{*}{$\begin{array}{l}\text { Electrical, Electronic \& } \\
\text { Mechanical }\end{array}$} & $-0.8079^{* \star *}$ & $-0.8482^{\star \star \star}$ & $-0.8328^{\star \star \star}$ & $-0.794^{\star * \star}$ & $-0.7848^{\star \star \star}$ & $-0.7804^{\star \star \star}$ \\
\hline & $(7.48)$ & $(7.89)$ & $(7.73)$ & $(7.28)$ & (7.18) & (7.19) \\
\hline \multirow[t]{2}{*}{ Other Field } & $-1.6143^{\star \star \star}$ & $-1.6205^{\star \star \star}$ & 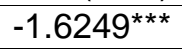 & $-1.6228^{\star \star \star}$ & $-1.6224^{\star \star \star}$ & $-1.6181^{\star \star \star}$ \\
\hline & (13.36) & (13.51) & (13.54) & (13.47) & (13.47) & (13.57) \\
\hline \multirow{2}{*}{$\begin{array}{l}\text { Log Stock of R\&D } \\
\text { Expenditure }\end{array}$} & $0.3277^{* * *}$ & $0.293^{\star \star \star}$ & $0.3014^{\star \star \star}$ & $0.3183^{\star \star \star}$ & $0.315^{\star \star \star}$ & \\
\hline & $(12.68)$ & $(11.08)$ & $(11.34)$ & $(11.85)$ & $(11.66)$ & \\
\hline \multirow[t]{2}{*}{$\begin{array}{l}\text { Log R\&D } \\
\text { Expenditure_4 }\end{array}$} & & & & & & $0.2399 * \star \star$ \\
\hline & & & & & & (5.67) \\
\hline \multirow[t]{2}{*}{$\begin{array}{l}\text { Log R\&D } \\
\text { Expenditure_5 }\end{array}$} & & & & & & $0.0718^{*}$ \\
\hline & & & & & & $(1.75)$ \\
\hline \multirow[t]{2}{*}{ Log Faculty_4 } & $0.0413^{\star}$ & $0.0545^{\star *}$ & $0.0455^{\star *}$ & 0.0355 & $0.0412^{*}$ & $0.0401^{*}$ \\
\hline & $(1.75)$ & $(2.4)$ & $(1.98)$ & $(1.52)$ & (1.73) & $(1.69)$ \\
\hline \multirow[t]{2}{*}{ US Postdocs_4 } & -0.0009 & & & -0.0327 & -0.0332 & -0.0325 \\
\hline & $(0.04)$ & & & (1.33) & $(1.37)$ & $(1.34)$ \\
\hline \multirow{2}{*}{$\begin{array}{l}\text { International } \\
\text { Postdocs_4 }\end{array}$} & $0.1113^{\star \star \star}$ & & & $0.0985^{\star \star \star}$ & $0.1036^{\star \star \star}$ & $0.102^{\star \star \star}$ \\
\hline & $(5.56)$ & & & $(4.72)$ & $(4.9)$ & $(4.83)$ \\
\hline \multirow[t]{2}{*}{ Stock of US PhDs } & & $0.1602^{\star \star \star}$ & & & $0.1088^{\star \star \star}$ & $0.1127^{\star \star \star}$ \\
\hline & & $(6.46)$ & & & $(3.74)$ & (3.9) \\
\hline \multirow[t]{2}{*}{$\begin{array}{l}\text { Stock of International } \\
\text { PhDs }\end{array}$} & & -0.0094 & & & & \\
\hline & & $(0.29)$ & & & & \\
\hline \multirow{2}{*}{$\begin{array}{l}\text { Stock of US \& } \\
\text { Permanent PhDs }\end{array}$} & & & $0.1473^{\star \star \star}$ & $0.0877^{\star \star \star}$ & & \\
\hline & & & $(8.92)$ & (3.98) & & \\
\hline \multirow[t]{2}{*}{$\begin{array}{l}\text { Stock of Permanent } \\
\text { Resident PhDs }\end{array}$} & & & & & -0.0175 & -0.0257 \\
\hline & & & & & $(0.18)$ & $(0.27)$ \\
\hline \multirow{2}{*}{$\begin{array}{l}\text { Stock of Temporary } \\
\text { Resident PhDs }\end{array}$} & & & $-0.0914^{\star *}$ & $-0.0965^{\star *}$ & $-0.0924^{\star \star}$ & $-0.0905^{\star \star}$ \\
\hline & & & $(2.25)$ & $(2.37)$ & $(2.29)$ & $(2.25)$ \\
\hline \multirow[t]{2}{*}{ Stock of Other PhDs } & & & $0.1514^{*}$ & $0.1714^{\star \star}$ & $0.1768^{\star *}$ & 0.1849 ** \\
\hline & & & $(1.85)$ & $(2.11)$ & $(2.2)$ & $(2.3)$ \\
\hline \multirow{2}{*}{$\begin{array}{l}\text { Technology Transfer } \\
\text { Office_4 }\end{array}$} & $0.2207^{* \star *}$ & 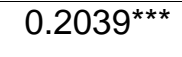 & $0.2144^{\star \star \star}$ & $0.2305^{\star \star \star}$ & $0.2311^{\star \star \star}$ & $0.2263^{\star \star \star}$ \\
\hline & (6.19) & $(5.75)$ & $(6.02)$ & $(6.44)$ & $(6.47)$ & (6.35) \\
\hline \multirow[t]{2}{*}{ Top 110 Institution } & $0.8105^{\star \star \star}$ & $0.7834^{\star \star \star}$ & $0.7825^{\star \star \star}$ & $0.7935^{\star \star \star}$ & $0.7901^{\star \star \star}$ & $0.7785^{\star \star \star}$ \\
\hline & (8.69) & (8.53) & (8.5) & $(8.56)$ & (8.53) & $(8.46)$ \\
\hline Minus log-likelihood & 13467 & 13482 & 13473 & 13457 & 13456 & 13445 \\
\hline
\end{tabular}




\begin{tabular}{|l|l|l|l|l|l|l|}
\hline AIC & 26990 & 27019 & 27004 & 26975 & 26976 & 26955 \\
\hline BIC & 27197 & 27226 & 27219 & 27204 & 27213 & 27199 \\
\hline
\end{tabular}

Notes:

(a) Absolute value of t statistics within parentheses.

(b) *, ${ }^{* *}$ and $* * *$ indicate statistical significance at $10 \%, 5 \%$, and $1 \%$ respectively.

(c) All specifications control for year effects.

(d) Results for postdoc and PhD variables are expressed in 100s. 
Table 5. Estimation Results from Individual Effects Model for Top Ranked Institutions (1985-1999) Dependent Variable: Patent Issued to Top Institutions in all Fields

\begin{tabular}{|c|c|c|c|}
\hline \multirow[t]{2}{*}{ Variable } & \multicolumn{3}{|c|}{ Specification 4} \\
\hline & Top 110 Programs & Top 25 Programs & Top 10 programs \\
\hline \multirow[t]{2}{*}{$\begin{array}{l}\text { Computer \& } \\
\text { Communications }\end{array}$} & $-0.7696 * * *$ & $-0.7141^{* * *}$ & $-0.5960 * * *$ \\
\hline & $(6.66)$ & $(5.57)$ & $(4.11)$ \\
\hline \multirow[t]{2}{*}{ Drugs \& Medical } & $-0.6218 * * *$ & $-0.4757 * * *$ & $-0.4551 * * *$ \\
\hline & $(5.30)$ & (3.62) & (2.93) \\
\hline \multirow[t]{2}{*}{$\begin{array}{l}\text { Electrical, Electronic \& } \\
\text { Mechanical }\end{array}$} & $-0.8274 * * *$ & $-0.7663 * * *$ & $-0.7255^{* * *}$ \\
\hline & $(7.54)$ & $(6.32)$ & (5.12) \\
\hline \multirow[t]{2}{*}{ Other Field } & $-1.8663 * * *$ & $-1.7523 * * *$ & $-1.8081^{* * *}$ \\
\hline & $(15.29)$ & (13.05) & $(11.70)$ \\
\hline \multirow[t]{2}{*}{$\begin{array}{l}\text { Log Stock of R\&D } \\
\text { Expenditure }\end{array}$} & $0.3921 * * *$ & $0.3852 * * *$ & $0.3521 * * *$ \\
\hline & $(12.94)$ & $(11.06)$ & $(7.97)$ \\
\hline \multirow[t]{2}{*}{ Log faculty_4 } & $0.0524 * *$ & 0.0311 & 0.0064 \\
\hline & $(2.14)$ & $(1.20)$ & $(0.21)$ \\
\hline \multirow[t]{2}{*}{ All Postdocs_4 } & $0.0462 * * *$ & $0.0469 * * *$ & $0.0415 * * *$ \\
\hline & $(5.71)$ & $(5.66)$ & $(4.85)$ \\
\hline \multirow[t]{2}{*}{ Stock of All PhDs } & $0.0412 * *$ & $0.0335 *$ & $0.0439 * *$ \\
\hline & $(2.53)$ & $(1.94)$ & (2.46) \\
\hline \multirow[t]{2}{*}{$\begin{array}{l}\text { Technology Transfer } \\
\text { Office }\end{array}$} & $0.2437 * * *$ & $0.1900 * * *$ & $0.1415^{* *}$ \\
\hline & $(6.31)$ & $(4.41)$ & $(2.55)$ \\
\hline Observations & 6837 & 4703 & 2471 \\
\hline Minus log likelihood & 10720 & 8252 & 5091 \\
\hline AIC & 21495 & 16558 & 10235 \\
\hline BIC & 21679 & 16730 & 10392 \\
\hline
\end{tabular}

Notes:
(a) Absolute value of $t$ statistics within parentheses.
(b) *, ** and *** indicate statistical significance at $10 \%, 5 \%$, and $1 \%$ respectively.
(c) All specifications control for year effects.
(d) Results for postdoc and $\mathrm{PhD}$ variables are expressed in 100s. 
Table 5 Continued

\begin{tabular}{|c|c|c|c|}
\hline \multirow[t]{2}{*}{ Variable } & \multicolumn{3}{|c|}{ Specification 10} \\
\hline & Top 110 Programs & Top 25 Programs & Top 10 Programs \\
\hline \multirow{3}{*}{$\begin{array}{l}\text { Computer \& } \\
\text { Communications }\end{array}$} & $-0.747^{* * *}$ & $-0.6860^{* * *}$ & $-0.5409^{* * *}$ \\
\hline & & & \\
\hline & $(6.49)$ & (5.38) & $(3.74)$ \\
\hline \multirow[t]{2}{*}{ Drugs \& Medical } & $-0.632 * * *$ & $-0.4792 * * *$ & $-0.4260 * * *$ \\
\hline & (5.36) & (3.64) & $(2.74)$ \\
\hline \multirow{3}{*}{$\begin{array}{l}\text { Electrical, Electronic \& } \\
\text { Mechanical }\end{array}$} & $-0.767 * * *$ & $-0.6862 * * *$ & $-0.5669 * * *$ \\
\hline & & & \\
\hline & $(6.87)$ & $(5.55)$ & $(3.84)$ \\
\hline \multirow{2}{*}{ Other Field } & $-1.880 * * *$ & $-1.7630 * * *$ & $-1.7996 * * *$ \\
\hline & $(15.42)$ & $(13.16)$ & $(11.63)$ \\
\hline \multirow{3}{*}{$\begin{array}{l}\text { Log Stock of R\&D } \\
\text { Expenditure }\end{array}$} & $0.399 * * *$ & $0.3950 * * *$ & $0.3520 * * *$ \\
\hline & & & \\
\hline & (12.99) & (11.19) & $(7.80)$ \\
\hline \multirow[t]{2}{*}{ Log faculty_4 } & $0.054 * *$ & 0.0318 & 0.0135 \\
\hline & (2.15) & $(1.20)$ & $(0.44)$ \\
\hline \multirow[t]{2}{*}{ US Postdocs_4 } & -0.035 & -0.0402 & -0.0414 \\
\hline & $(1.42)$ & $(1.63)$ & $(1.64)$ \\
\hline \multirow[t]{2}{*}{ International Postdocs_4 } & $0.105^{* * *}$ & $0.1084^{* * *}$ & $0.1097 * * *$ \\
\hline & (4.92) & $(5.02)$ & $(4.85)$ \\
\hline \multirow[t]{2}{*}{ Stock of US PhDs } & $0.122 * * *$ & $0.1150^{* * *}$ & $0.1559 * * *$ \\
\hline & (4.30) & (3.99) & (5.20) \\
\hline \multirow{3}{*}{$\begin{array}{l}\text { Stock of Permanent } \\
\text { Resident PhDs }\end{array}$} & -0.088 & -0.0730 & $-0.2205^{*}$ \\
\hline & & & \\
\hline & $(0.90)$ & $(0.72)$ & $(1.94)$ \\
\hline \multirow{3}{*}{$\begin{array}{l}\text { Stock of Temporary } \\
\text { Resident PhDs }\end{array}$} & $-0.079 *$ & $-0.1022^{* *}$ & $-0.1140^{* *}$ \\
\hline & & & \\
\hline & $(1.92)$ & (2.37) & (2.38) \\
\hline \multirow[t]{2}{*}{ Stock of Other PhDs } & $0.211^{* * *}$ & $0.2089 * * *$ & $0.2098 * *$ \\
\hline & $(2.66)$ & $(2.58)$ & $(2.45)$ \\
\hline \multirow{2}{*}{$\begin{array}{l}\text { Technology Transfer } \\
\text { Office }\end{array}$} & $0.263 * * *$ & $0.2142^{* * *}$ & $0.1899 * * *$ \\
\hline & $(6.81)$ & $(4.96)$ & (3.39) \\
\hline & & & \\
\hline Observations & 6837 & 4703 & 2471 \\
\hline Minus log likelihood & 10707 & 8238 & 5074 \\
\hline AIC & 21476 & 16537 & 10210 \\
\hline BIC & 21688 & 16737 & 10390 \\
\hline
\end{tabular}

Notes:
(a) Absolute value of $t$ statistics within parentheses.
(b) *, ** and *** indicate statistical significance at $10 \%, 5 \%$, and $1 \%$ respectively.
(c) All specifications control for year effects.
(d) Results for postdoc and PhD variables are expressed in 100s. 
Figure 1

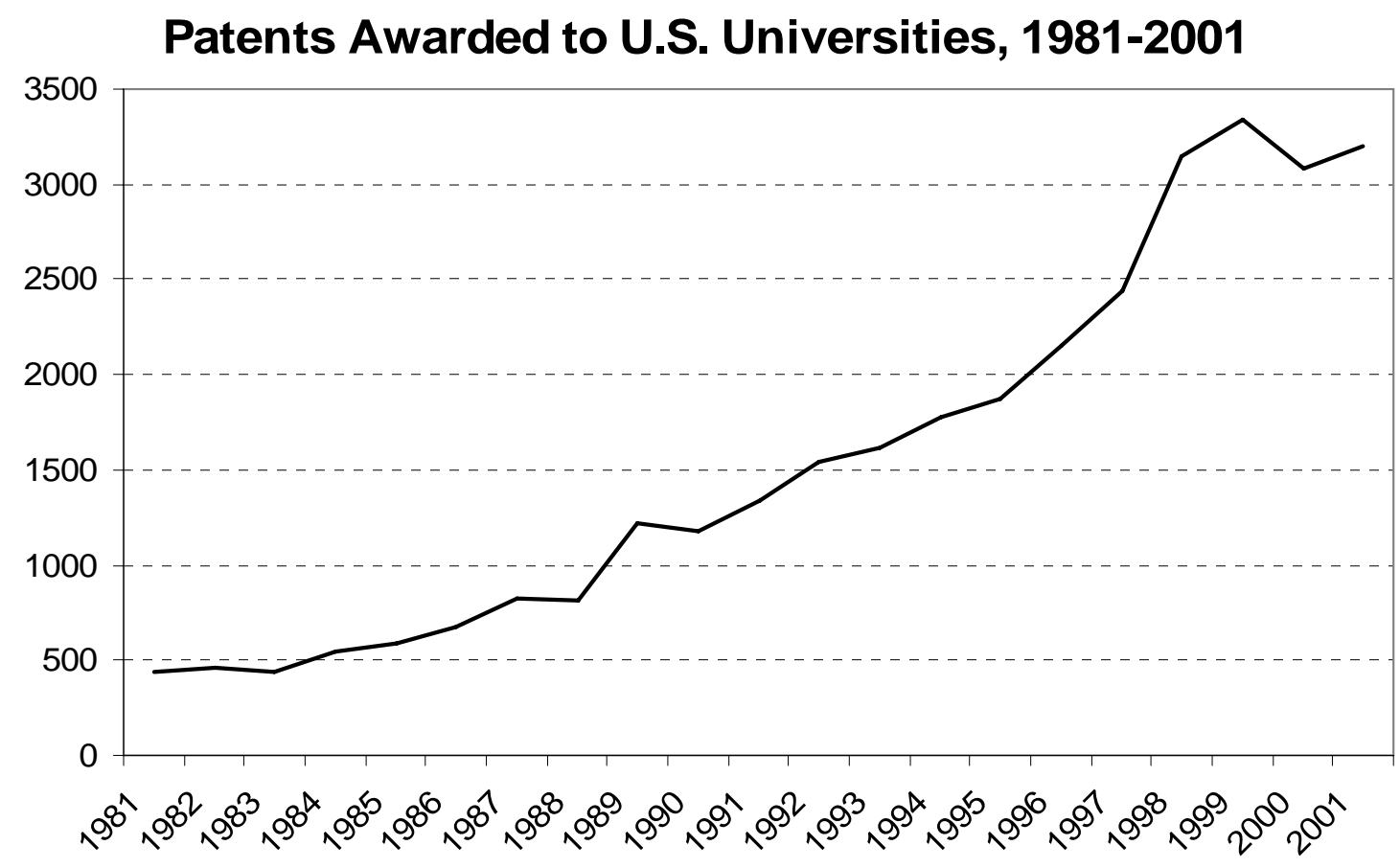

Source: National Science Board, 2004, Table A5-54. 
Figure 2

Citizenship Status of S\&E Doctorates by Year of Degree

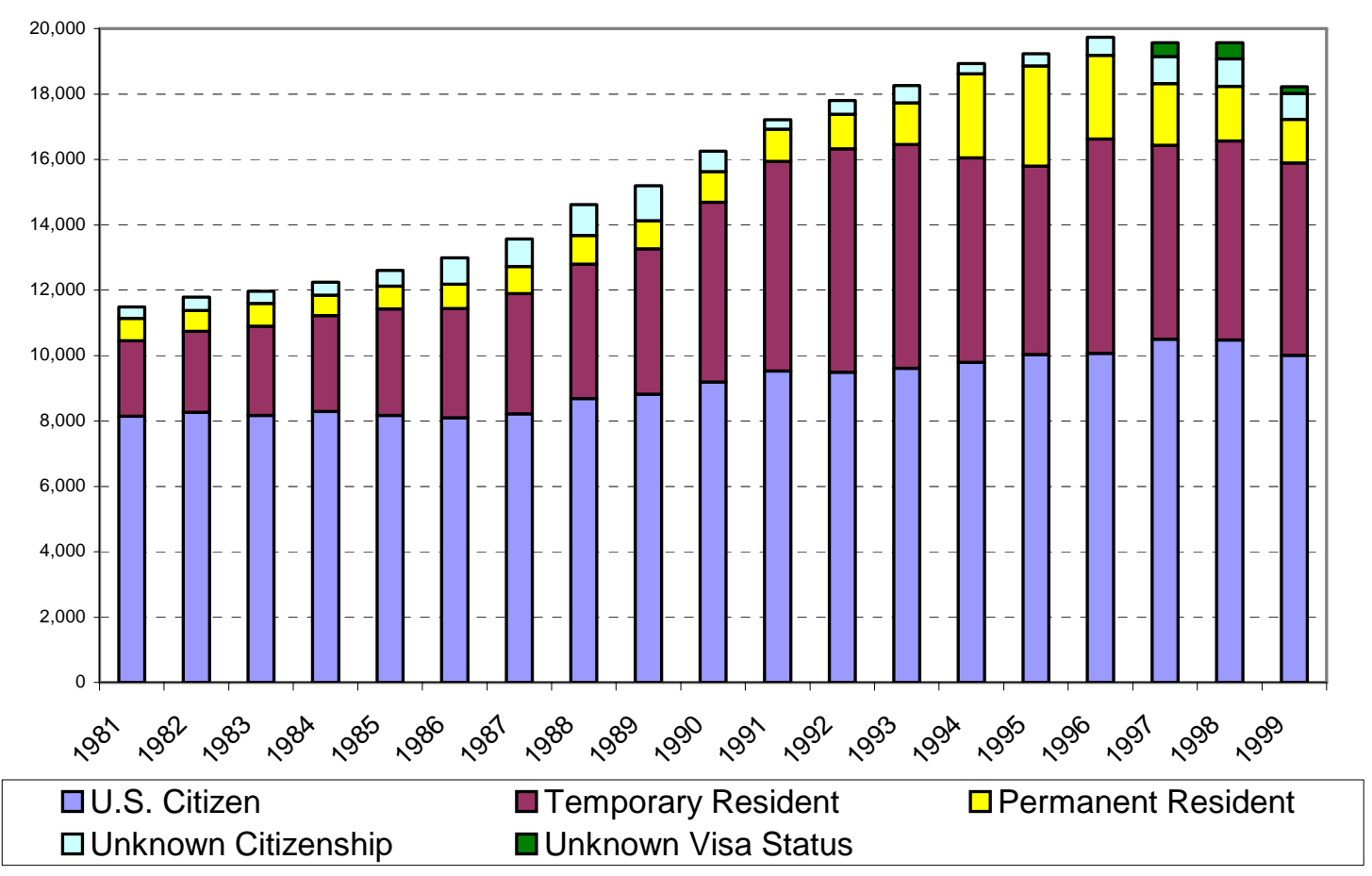


Appendix A

Web Tables - Summary Statistics and Results by Major Academic Fields (Not for Publication) 
Table A1. Means (Standard Deviations) for All Institutions by Academic Field ( 1985-1999)

\begin{tabular}{|c|c|c|c|c|c|}
\hline \multirow[t]{3}{*}{ Variable } & Chemical & $\begin{array}{l}\text { Computer } \\
\&\end{array}$ & Drugs \& & Electrical, & Other \\
\hline & & Commu- & Medical & $\begin{array}{l}\text { Electronic } \\
\text { s \& }\end{array}$ & Fields \\
\hline & & nications & & $\begin{array}{l}\text { Mechan- } \\
\text { ical }\end{array}$ & \\
\hline \multirow[t]{2}{*}{ Patent Issued } & 2.249 & 0.77 & 3.592 & 2.075 & 0.461 \\
\hline & $(4.89)$ & $(2.49)$ & $(9.11)$ & $(6.01)$ & $(1.23)$ \\
\hline \multirow[t]{2}{*}{ Stock of R\&D Expenditure } & 17991.975 & 12025.113 & 142022.90 & 69091.006 & 80302.241 \\
\hline & $(23916.29)$ & $(29121.94)$ & $(264428.5)$ & $(12988.10)$ & $(143303.1)$ \\
\hline \multirow[t]{2}{*}{ R\&D Expenditure } & 6087.014 & 4456.591 & 52007.061 & 24226.935 & 26448.054 \\
\hline & (7861.68) & $(9943.6)$ & (97271.89) & (43108.25) & (43861.55) \\
\hline \multirow[t]{2}{*}{ Faculty } & 1092.815 & 1179.833 & 1104.507 & 1110.23 & 1080.923 \\
\hline & $(957.02)$ & $(1004.55)$ & $(956.58)$ & $(967.4)$ & $(955.12)$ \\
\hline \multirow[t]{2}{*}{ All Postdocs } & 23.886 & 1.171 & 122.184 & 21.263 & 11.735 \\
\hline & (39.54) & (3.51) & $(302.97)$ & $(38.23)$ & $(26.83)$ \\
\hline \multirow[t]{2}{*}{ US Postdocs - Total: } & 8.902 & 0.613 & 66.515 & 8.498 & 6.899 \\
\hline & $(18.29)$ & $(1.82)$ & $(169.62)$ & $(16.44)$ & $(16.72)$ \\
\hline \multirow[t]{2}{*}{ Medical US Postdocs } & 0.045 & 0.04 & 18.447 & 0.104 & 0.266 \\
\hline & $(0.53)$ & $(0.58)$ & $(58.45)$ & $(0.60)$ & $(1.45)$ \\
\hline \multirow[t]{2}{*}{ Non-Medical US Postdocs } & 8.857 & 0.572 & 48.069 & 8.394 & 6.634 \\
\hline & (18.18) & $(1.71)$ & $(115.09)$ & $(16.31)$ & $(15.97)$ \\
\hline \multirow[t]{2}{*}{ International Postdocs -Total: } & 14.984 & 0.558 & 55.669 & 12.765 & 4.836 \\
\hline & $(22.76)$ & $(2.09)$ & $(138.17)$ & $(23.74)$ & (10.9) \\
\hline \multirow[t]{2}{*}{ Medical International Postdocs } & 0.11 & 0.004 & 15.856 & 0.147 & 0.179 \\
\hline & $(1.16)$ & $(0.07)$ & $(49.6)$ & $(0.98)$ & $(0.95)$ \\
\hline \multirow{2}{*}{$\begin{array}{l}\text { Non-medical International } \\
\text { Postdocs }\end{array}$} & 14.874 & 0.554 & 39.813 & 12.618 & 4.656 \\
\hline & $(22.51)$ & $(2.07)$ & (92.66) & $(23.49)$ & $(10.55)$ \\
\hline \multirow[t]{2}{*}{ Stock of All PhDs } & 60.530 & 21.486 & 108.273 & 120.773 & 84.767 \\
\hline & $(86.04)$ & $(34.91)$ & $(175.52)$ & $(195.75)$ & $(128.52)$ \\
\hline \multirow[t]{2}{*}{ Stock of US PhDs } & 37.275 & 10.080 & 78.594 & 51.694 & 51.768 \\
\hline & $(62.69)$ & $(17.74)$ & $(132.37)$ & $(94.47)$ & $(81.72)$ \\
\hline \multirow[t]{2}{*}{ Stock of International PhDs -Total: } & 23.255 & 11.406 & 29.680 & 69.079 & 33.000 \\
\hline & $(27.86)$ & $(18.42)$ & $(47.90)$ & $(105.32)$ & $(50.10)$ \\
\hline \multirow{2}{*}{$\begin{array}{l}\text { Stock of Permanent Resident } \\
\text { PhDs }\end{array}$} & 4.486 & 2.197 & 7.261 & 11.764 & 5.181 \\
\hline & $(6.56)$ & $(4.15)$ & $(13.99)$ & $(19.97)$ & $(9.22)$ \\
\hline \multirow{2}{*}{$\begin{array}{l}\text { Stock of Temporary Resident } \\
\text { PhDs }\end{array}$} & 16.594 & 8.509 & 19.212 & 51.45 & 24.412 \\
\hline & (19.71) & (13.86) & (31.28) & $(76.70)$ & (37.72) \\
\hline \multirow{2}{*}{$\begin{array}{l}\text { Stock of Other } \\
\text { PhDs }\end{array}$} & 2.176 & 0.700 & 3.207 & 5.860 & 3.407 \\
\hline & $(5.94)$ & $(2.33)$ & $(8.29)$ & $(21.58)$ & $(1029)$ \\
\hline \multirow[t]{2}{*}{ Technology Transfer Office } & 0.516 & 0.571 & 0.515 & 0.528 & 0.509 \\
\hline & $(0.50)$ & $(0.50)$ & $(0.50)$ & $(0.50)$ & $(0.50)$ \\
\hline \multirow[t]{2}{*}{ Top 110 Institution } & 0.554 & 0.621 & 0.565 & 0.564 & 0.553 \\
\hline & $(0.50)$ & $(0.49)$ & $(0.5)$ & $(0.5)$ & $(0.5)$ \\
\hline Top 25 in Chemical Field & 0.193 & 0.226 & 0.194 & 0.199 & 0.19 \\
\hline
\end{tabular}




\begin{tabular}{|l|r|r|r|r|r|}
\hline & $(0.40)$ & $(0.42)$ & $(0.40)$ & $(0.40)$ & $(0.39)$ \\
\hline $\begin{array}{l}\text { Top 25 in Computer \& } \\
\text { Communication }\end{array}$ & 0.139 & 0.162 & 0.14 & 0.143 & 0.137 \\
\hline & $(0.35)$ & $(0.37)$ & $(0.35)$ & $(0.35)$ & $(0.34)$ \\
\hline Top 25 in Drugs \& Medical & 0.187 & 0.213 & 0.188 & 0.191 & 0.184 \\
\hline & $(0.39)$ & $(0.41)$ & $(0.39)$ & $(0.39)$ & $(0.39)$ \\
\hline $\begin{array}{l}\text { Top 25 in Electric, Electronics \& } \\
\text { Mechanical }\end{array}$ & 0.325 & 0.381 & 0.328 & 0.336 & 0.321 \\
\hline & $(0.47)$ & $(0.49)$ & $(0.47)$ & $(0.47)$ & $(0.47)$ \\
\hline Top 25 & 0.38 & 0.441 & 0.383 & 0.39 & 0.375 \\
\hline & $(0.49)$ & $(0.5)$ & $(0.49)$ & $(0.49)$ & $(0.48)$ \\
\hline Top 10 in Chemical Field & 0.084 & 0.098 & 0.085 & 0.087 & 0.083 \\
\hline & $(0.28)$ & $(0.3)$ & $(0.28)$ & $(0.28)$ & $(0.28)$ \\
\hline Top 10 in Computer \& & 0.06 & 0.071 & 0.061 & 0.062 & 0.059 \\
Communications & $(0.24)$ & $(0.26)$ & $(0.24)$ & $(0.24)$ & $(0.24)$ \\
\hline Top 10 in Drugs \& Medical & 0.078 & 0.093 & 0.079 & 0.081 & 0.077 \\
\hline & $(0.27)$ & $(0.29)$ & $(0.27)$ & $(0.27)$ & $(0.27)$ \\
\hline Top 10 in Electric, Electronics \& & 0.157 & 0.183 & 0.158 & 0.162 & 0.155 \\
Mech & & & & & $(0.36)$ \\
\hline & $(0.36)$ & $(0.39)$ & $(0.37)$ & $(0.37)$ & $(0.36)$ \\
\hline Top 10 & 0.199 & 0.233 & 0.201 & 0.205 & 0.196 \\
\hline & $(0.40)$ & $(0.42)$ & $(0.40)$ & $(0.40)$ & $(0.40)$ \\
\hline Number of Observations & 2490 & 2105 & 2468 & 2411 & 2523 \\
\hline Number of Programs (Institutions) & 166 & 155 & 165 & 164 & 169 \\
\hline
\end{tabular}


Table A2. Means (Standard Deviations) by Major Academic Fields for Top 110 Ranked Institutions (1985-1999)

\begin{tabular}{|c|c|c|c|c|c|}
\hline \multirow[t]{3}{*}{ Variable } & Chemical & $\begin{array}{l}\text { Computer } \\
\&\end{array}$ & Drugs \& & Electrical, & Other \\
\hline & & Commu- & Medical & $\begin{array}{l}\text { Electronics } \\
\&\end{array}$ & Fields \\
\hline & & nications & & Mechanical & \\
\hline \multirow[t]{2}{*}{ Patent Issued } & 3.60 & 1.187 & 5.993 & 3.420 & 0.721 \\
\hline & $(6.14)$ & $(3.07)$ & (11.50) & $(7.70)$ & (1.54) \\
\hline \multirow[t]{2}{*}{ Stock of R\&D Expenditure } & 27233.480 & 17850.223 & 236608.40 & 108040.90 & 124607.10 \\
\hline & $(28255.37)$ & (35652.59) & (320243.6) & $(16619.20)$ & $(17533.70)$ \\
\hline \multirow[t]{2}{*}{ R\&D Expenditure } & 9169.100 & 6710.738 & 86646.536 & 37813.589 & 40755.459 \\
\hline & $(9217.65)$ & (12048.74) & $(118000)$ & $(53254.28)$ & (53777.63) \\
\hline \multirow[t]{2}{*}{ Faculty } & 1361.170 & 1420.968 & 1351.916 & 1372.646 & 1347.637 \\
\hline & $(1164.37)$ & (1177.57) & $(1162.74)$ & (1169.18) & (1163.8) \\
\hline \multirow[t]{2}{*}{ All Postdocs } & 37.35 & 1.792 & 208.395 & 33.840 & 19.506 \\
\hline & (48.39) & (4.28) & (380.96) & (46.8) & (33.97) \\
\hline \multirow[t]{2}{*}{ US Postdocs - Total: } & 14.550 & 0.925 & 113.997 & 13.668 & 11.480 \\
\hline & (22.86) & (2.15) & $(213.7)$ & $(20.23)$ & (21.27) \\
\hline \multirow[t]{2}{*}{ Medical US Postdocs } & 0.080 & 0.030 & 32.205 & 0.141 & 0.444 \\
\hline & $(0.70)$ & $(0.38)$ & (74.88) & $(0.67)$ & $(1.91)$ \\
\hline \multirow[t]{2}{*}{ Non-Medical US Postdocs } & 14.480 & 0.895 & 81.792 & 13.527 & 11.036 \\
\hline & $(22.72)$ & $(2.09)$ & $(144.16)$ & $(20.07)$ & $(20.29)$ \\
\hline \multirow[t]{2}{*}{ International Postdocs -Total: } & 22.800 & 0.867 & 94.398 & 20.171 & 8.027 \\
\hline & $(27.44)$ & $(2.59)$ & $(173.96)$ & $(29.25)$ & (13.73) \\
\hline \multirow[t]{2}{*}{ Medical International Postdocs } & 0.163 & 0.005 & 27.285 & 0.211 & 0.280 \\
\hline & (1.49) & $(0.07)$ & $(63.62)$ & $(1.21)$ & (1.13) \\
\hline \multirow[t]{2}{*}{$\begin{array}{l}\text { Non-medical International } \\
\text { Postdocs }\end{array}$} & 22.64 & 0.862 & 67.113 & 19.96 & 7.747 \\
\hline & (27.1) & $(2.57)$ & (115.89) & $(28.93)$ & (13.31) \\
\hline \multirow[t]{2}{*}{ Stock of All PhDs } & 92.729 & 30.023 & 170.879 & 186.063 & 133.978 \\
\hline & (103.36) & $(40.73)$ & $(212.25)$ & $(238.26)$ & $(153.96)$ \\
\hline \multirow[t]{2}{*}{ Stock of US PhDs } & 59.337 & 14.347 & 125.016 & 81.159 & 82.063 \\
\hline & $(76.84)$ & (20.98) & $(160.71)$ & (116.65) & (98.91) \\
\hline \multirow{2}{*}{$\begin{array}{l}\text { Stock of International PhDs - } \\
\text { Total: }\end{array}$} & 33.392 & 15.676 & 45.863 & 104.904 & 51.914 \\
\hline & (32.38) & $(21.31)$ & $(58.23)$ & $(127.10)$ & (59.68) \\
\hline \multirow{2}{*}{$\begin{array}{l}\text { Stock of Permanent Resident } \\
\text { PhDs }\end{array}$} & 6.941 & 2.972 & 11.209 & 17.410 & 8.072 \\
\hline & $(7.90)$ & $(4.88)$ & $(17.42)$ & $(24.71)$ & $(11.44)$ \\
\hline \multirow{2}{*}{$\begin{array}{l}\text { Stock of Temporary Resident } \\
\text { PhDs }\end{array}$} & 23.519 & 11.696 & 29.662 & 78.200 & 38.206 \\
\hline & $(22.72)$ & $(15.94)$ & $(38.04)$ & $(91.83)$ & $(44.92)$ \\
\hline \multirow{2}{*}{$\begin{array}{l}\text { Stock of Other } \\
\text { PhDs }\end{array}$} & 3.383 & 1.008 & 4.992 & 9.295 & 5.637 \\
\hline & (7.65) & $(2.87)$ & $(10.53)$ & $(28.07)$ & $(13.51)$ \\
\hline \multirow[t]{2}{*}{ Technology Transfer Office } & 0.735 & 0.740 & 0.727 & 0.742 & 0.727 \\
\hline & $(0.44)$ & $(0.44)$ & $(0.45)$ & $(0.44)$ & $(0.45)$ \\
\hline \multirow[t]{2}{*}{ Top 25 in Chemical Field } & 0.348 & 0.364 & 0.344 & 0.353 & 0.344 \\
\hline & $(0.48)$ & $(0.48)$ & $(0.48)$ & $(0.48)$ & $(0.48)$ \\
\hline
\end{tabular}




\begin{tabular}{|c|c|c|c|c|c|}
\hline $\begin{array}{l}\text { Top } 25 \text { in Computer \& } \\
\text { Communication }\end{array}$ & 0.25 & 0.261 & 0.247 & 0.254 & 0.247 \\
\hline & $(0.43)$ & $(0.44)$ & $(0.43)$ & $(0.44)$ & $(0.43)$ \\
\hline \multirow[t]{2}{*}{ Top 25 in Drugs \& Medical } & 0.326 & 0.334 & 0.323 & 0.327 & 0.323 \\
\hline & $(0.47)$ & $(0.47)$ & $(0.47)$ & $(0.47)$ & $(0.47)$ \\
\hline \multirow[t]{2}{*}{$\begin{array}{l}\text { Top } 25 \text { in Electric, Electronics \& } \\
\text { Mechanical }\end{array}$} & 0.587 & 0.614 & 0.581 & 0.596 & 0.581 \\
\hline & $(0.49)$ & $(0.49)$ & $(0.49)$ & $(0.49)$ & $(0.49)$ \\
\hline \multirow[t]{2}{*}{ Top 25} & 0.674 & 0.7 & 0.667 & 0.68 & 0.667 \\
\hline & $(0.47)$ & $(0.46)$ & $(0.47)$ & $(0.47)$ & $(0.47)$ \\
\hline \multirow[t]{2}{*}{ Top 10 in Chemical Field } & 0.152 & 0.158 & 0.151 & 0.154 & 0.151 \\
\hline & $(0.36)$ & $(0.37)$ & $(0.36)$ & $(0.36)$ & $(0.36)$ \\
\hline \multirow[t]{2}{*}{$\begin{array}{l}\text { Top } 10 \text { in Computer \& } \\
\text { Communications }\end{array}$} & 0.109 & 0.115 & 0.108 & 0.11 & 0.108 \\
\hline & $(0.31)$ & $(0.32)$ & $(0.31)$ & $(0.31)$ & $(0.31)$ \\
\hline \multirow[t]{2}{*}{ Top 10 in Drugs \& Medical } & 0.141 & 0.149 & 0.14 & 0.143 & 0.14 \\
\hline & $(0.35)$ & $(0.36)$ & $(0.35)$ & $(0.35)$ & $(0.35)$ \\
\hline \multirow[t]{2}{*}{$\begin{array}{l}\text { Top } 10 \text { in Electric, Electronics \& } \\
\text { Mechanical }\end{array}$} & 0.283 & 0.295 & 0.28 & 0.287 & 0.28 \\
\hline & $(0.45)$ & $(0.46)$ & $(0.45)$ & $(0.45)$ & $(0.45)$ \\
\hline \multirow[t]{2}{*}{ Top 10} & 0.359 & 0.376 & 0.355 & 0.364 & 0.355 \\
\hline & $(0.48)$ & $(0.48)$ & $(0.48)$ & $(0.48)$ & $(0.48)$ \\
\hline Number of Observations & 1380 & 1307 & 1395 & 1360 & 1395 \\
\hline Number of Programs & 92 & 90 & 93 & 91 & 93 \\
\hline
\end{tabular}


Table A3. Results from Individual Effects Model by Academic Field with Top 110 Ranking Dummy Variable (1985-1999) Dependent Variable: Patent Issued to All Institutions

\begin{tabular}{|c|c|c|c|c|c|}
\hline \multirow[t]{2}{*}{ Variable } & \multicolumn{5}{|c|}{ Specification 4} \\
\hline & Chemical & $\begin{array}{c}\text { Computer \& } \\
\text { Communications }\end{array}$ & $\begin{array}{l}\text { Drugs\& } \\
\text { Medical }\end{array}$ & $\begin{array}{l}\text { Electrical, } \\
\text { Electronic } \\
\text { and } \\
\text { Mechanical }\end{array}$ & Other Field \\
\hline \multirow[t]{2}{*}{$\begin{array}{l}\text { Log Stock of R\&D } \\
\text { Expenditure }\end{array}$} & $0.2168 * * *$ & $0.1866 * * *$ & $0.3828 * * *$ & $0.3615^{* * *}$ & $0.2357 * * *$ \\
\hline & (3.12) & $(2.90)$ & $(6.77)$ & $(6.14)$ & $(3.42)$ \\
\hline \multirow[t]{2}{*}{ Log faculty_4 } & 0.0587 & -0.0448 & 0.0250 & $0.1001 * *$ & -0.0489 \\
\hline & $(1.23)$ & $(0.57)$ & $(0.62)$ & $(2.24)$ & $(0.56)$ \\
\hline \multirow[t]{2}{*}{ All Postdocs_4 } & $0.3379 * *$ & -0.6551 & $0.0259 *$ & $0.2025 * *$ & 0.2474 \\
\hline & $(2.23)$ & $(0.59)$ & (1.94) & $(2.02)$ & $(1.27)$ \\
\hline \multirow[t]{2}{*}{ Stock of All PhDs } & $-0.1788 * * *$ & $0.6330 * * *$ & -0.0016 & $0.1008 * * *$ & $0.3172 * * *$ \\
\hline & $(2.84)$ & $(4.16)$ & $(0.05)$ & (4.13) & (3.61) \\
\hline \multirow[t]{2}{*}{$\begin{array}{l}\text { Technology } \\
\text { Transfer Office }\end{array}$} & $0.3128 * * *$ & 0.2024 & $0.1786 * * *$ & $0.1300^{*}$ & $0.2446 * *$ \\
\hline & $(4.51)$ & $(1.63)$ & (2.93) & $(1.74)$ & $(2.04)$ \\
\hline \multirow[t]{2}{*}{ Top 110 Institution } & $0.8773 * * *$ & $1.3931^{* * *}$ & $0.8258 * * *$ & $0.7518^{* * *}$ & 0.3419 \\
\hline & (4.53) & $(5.06)$ & $(3.82)$ & $(4.15)$ & $(1.46)$ \\
\hline Observations & 2490 & 2105 & 2468 & 2411 & 2523 \\
\hline $\begin{array}{l}\text { Minus log } \\
\text { likelihood }\end{array}$ & 3503 & 1552 & 3616 & 2940 & 1620 \\
\hline AIC & 7054 & 3153 & 7280 & 5928 & 3288 \\
\hline $\mathrm{BIC}$ & 7194 & 3289 & 7419 & 6066 & 3428 \\
\hline
\end{tabular}

Notes:
(a) Absolute value of t statistics within parentheses.
(b) *, ** and *** indicate statistical significance at $10 \%, 5 \%$, and $1 \%$ respectively.
(c) All specifications control for year effects.
(d) Results for postdoc and PhD variables are expressed in 100s. 
Table A3 Continued

\begin{tabular}{|l|r|r|r|r|r|}
\hline & \multicolumn{5}{|c|}{ Specification 10 } \\
\hline \multicolumn{1}{|c|}{ Variable } & Chemical & \multicolumn{1}{|c|}{$\begin{array}{c}\text { Computer \& } \\
\text { Communications } \\
\text { Medical }\end{array}$} & $\begin{array}{c}\text { Electrical, } \\
\text { Electronic } \\
\text { and } \\
\text { Mechanical }\end{array}$ & Other Field \\
\hline $\begin{array}{l}\text { Log Stock of R\&D } \\
\text { Expenditure }\end{array}$ & $0.2098^{* * *}$ & $0.2049^{* * *}$ & $0.3602^{* * *}$ & $0.3942^{* * *}$ & $0.2378^{* * *}$ \\
\hline & $(3.10)$ & $(3.23)$ & $(6.35)$ & $(6.44)$ & $(3.35)$ \\
\hline Log faculty_4 & 0.0431 & -0.0456 & 0.0491 & 0.0609 & -0.0544 \\
\hline & $(0.96)$ & $(0.58)$ & $(1.28)$ & $(1.29)$ & $(0.60)$ \\
\hline US Postdocs_4 & 0.1215 & 0.4083 & 0.0175 & 0.1084 & 0.2431 \\
\hline & $(0.65)$ & $(0.24)$ & $(0.65)$ & $(0.65)$ & $(0.86)$ \\
\hline $\begin{array}{l}\text { International } \\
\text { Postdocs_4 }\end{array}$ & $0.7415^{* * *}$ & $-2.9622^{*}$ & 0.0202 & $0.2780^{*}$ & 0.0008 \\
\hline & $(5.13)$ & $(1.78)$ & $(0.71)$ & $(1.70)$ & $(0.00)$ \\
\hline Stock of US PhDs & $0.2094^{*}$ & $1.0627^{* * *}$ & $0.2415^{* * *}$ & $0.1461^{* *}$ & $0.3486^{* *}$ \\
\hline & $(1.82)$ & $(3.23)$ & $(4.21)$ & $(2.34)$ & $(2.25)$ \\
\hline $\begin{array}{l}\text { Stock of Permanent } \\
\text { Resident PhDs }\end{array}$ & 0.3904 & 1.3843 & $-0.5901^{* * *}$ & 0.2861 & 0.4960 \\
\hline & $(1.02)$ & $(1.10)$ & $(4.41)$ & $(1.36)$ & $(0.92)$ \\
\hline $\begin{array}{l}\text { Stock of Temporary } \\
\text { Resident PhDs }\end{array}$ & $-0.7121^{* * *}$ & -0.1750 & -0.0740 & -0.0538 & 0.2462 \\
\hline & $(4.96)$ & $(0.39)$ & $(0.90)$ & $(1.04)$ & $(1.15)$ \\
\hline $\begin{array}{l}\text { Stock of Other } \\
\text { PhDs }\end{array}$ & $-0.5662^{*}$ & $3.7705^{* * *}$ & -0.0913 & $0.2607^{* * *}$ & 0.4274 \\
\hline & $(1.92)$ & $(3.60)$ & $(0.47)$ & $(3.07)$ & $(1.49)$ \\
\hline $\begin{array}{l}\text { Technology } \\
\text { Transfer Office }\end{array}$ & $0.3195^{* * *}$ & $0.2385^{*}$ & $0.2038^{* * *}$ & $0.1876^{* *}$ & $0.2451^{* *}$ \\
\hline & $(4.74)$ & $(1.89)$ & $(3.43)$ & $(2.43)$ & $(2.02)$ \\
\hline Top 110 Institution & $0.7601^{* * *}$ & $1.3243^{* * *}$ & $0.7416^{* * *}$ & $0.7474^{* * *}$ & 0.3380 \\
\hline $\begin{array}{l}\text { Minus Log- } \\
\text { likelihood }\end{array}$ & $(4.03)$ & $(4.97)$ & $(3.44)$ & $(4.11)$ & $(1.44)$ \\
\hline AIC & 3490 & 1546 & 3598 & 2930 & 1620 \\
\hline BIC & 7037 & 3147 & 7252 & 5916 & 3295 \\
\hline & & & 7415 & 6078 & 3458 \\
\hline
\end{tabular}

Notes:
(a) Absolute value of $\mathrm{t}$ statistics within parentheses.
(b) *,** and *** indicate statistical significance at $10 \%, 5 \%$, and $1 \%$ respectively.
(c) All specifications control for year effects.
(d) Results for postdoc and PhD variables are expressed in 100s. 
Table A4. Estimation Results from Individual Effects Model by Academic Field with Top 25 Field Ranking Dummy Variable (1985-1999) Dependent Variable: Patent Issued to All Institutions

\begin{tabular}{|c|c|c|c|c|}
\hline \multirow[t]{2}{*}{ Variable } & \multicolumn{4}{|c|}{ Specification 4} \\
\hline & Chemical & $\begin{array}{c}\text { Computer \& } \\
\text { Communications }\end{array}$ & Drugs\& Medical & $\begin{array}{l}\text { Electrical, } \\
\text { Electronic and } \\
\text { Mechanical }\end{array}$ \\
\hline \multirow{2}{*}{$\begin{array}{l}\text { Log Stock of R\&D } \\
\text { Expenditure }\end{array}$} & $0.2469 * * *$ & $0.2159 * * *$ & $0.4006 * * *$ & $0.3626 * * *$ \\
\hline & $(3.51)$ & $(3.46)$ & $(7.74)$ & $(5.89)$ \\
\hline \multirow[t]{2}{*}{ Log faculty_4 } & 0.0537 & 0.0119 & 0.0484 & $0.1013^{* *}$ \\
\hline & $(1.11)$ & $(0.15)$ & $(1.21)$ & $(2.28)$ \\
\hline \multirow[t]{2}{*}{ All Postdocs_4 } & $0.2992 *$ & -0.8828 & 0.0198 & $0.1992 * *$ \\
\hline & $(1.96)$ & $(0.80)$ & $(1.54)$ & $(1.99)$ \\
\hline \multirow[t]{2}{*}{ Stock of All PhDs } & $-0.2181 * * *$ & $0.5615^{* * *}$ & 0.0031 & $0.0962 * * *$ \\
\hline & $(3.41)$ & $(3.64)$ & $(0.09)$ & $(3.92)$ \\
\hline \multirow{2}{*}{$\begin{array}{l}\text { Technology Transfer } \\
\text { Office }\end{array}$} & $0.3250 * * *$ & 0.1954 & $0.1886 * * *$ & $0.1245 *$ \\
\hline & $(4.69)$ & $(1.57)$ & $(3.05)$ & $(1.67)$ \\
\hline \multirow[t]{2}{*}{ Top 25 in Chemical Field } & $0.5315^{* *}$ & & & \\
\hline & (2.49) & & & \\
\hline \multirow[t]{2}{*}{$\begin{array}{l}\text { Top } 25 \text { in Computer \& } \\
\text { Communications }\end{array}$} & & $0.8755^{* * *}$ & & \\
\hline & & (3.06) & & \\
\hline \multirow[t]{2}{*}{$\begin{array}{l}\text { Top } 25 \text { in drug \& } \\
\text { Medical }\end{array}$} & & & $0.8549 * * *$ & \\
\hline & & & $(4.23)$ & \\
\hline \multirow[t]{2}{*}{$\begin{array}{l}\text { Top } 25 \text { in Electric, } \\
\text { Electronics \& Mech. }\end{array}$} & & & & $0.4556 * * *$ \\
\hline & & & & $(2.61)$ \\
\hline Observations & 2490 & 2105 & 2468 & 2411 \\
\hline Minus log likelihood & 3509 & 1560 & 3613 & 2944 \\
\hline AIC & 7067 & 3168 & 7274 & 5937 \\
\hline BIC & 7206 & 3304 & 7414 & 6076 \\
\hline
\end{tabular}

Notes:

(a) Absolute value of t statistics within parentheses.

(b) *, $* *$ and $* * *$ indicate statistical significance at $10 \%, 5 \%$, and $1 \%$ respectively.

(c) All specifications control for year effects.

(d) Results for postdoc and $\mathrm{PhD}$ variables are expressed in 100s. 
Table A4 Continued

\begin{tabular}{|c|c|c|c|c|}
\hline \multirow[t]{2}{*}{ Variable } & \multicolumn{4}{|c|}{ Specification 10} \\
\hline & Chemical & $\begin{array}{l}\text { Computer \& } \\
\text { Communications }\end{array}$ & $\begin{array}{l}\text { Drugs \& } \\
\text { Medical }\end{array}$ & $\begin{array}{l}\text { Electrical, } \\
\text { Electronic \& } \\
\text { Mechanical }\end{array}$ \\
\hline \multirow{2}{*}{$\begin{array}{l}\text { Log Stock of R\&D } \\
\text { Expenditure }\end{array}$} & $0.2428 * * *$ & $0.2398 * * *$ & $0.3953 * * *$ & $0.3951^{* * *}$ \\
\hline & (3.53) & (3.85) & $(7.56)$ & $(6.20)$ \\
\hline \multirow[t]{2}{*}{ Log faculty_4 } & 0.0436 & 0.0070 & 0.0558 & 0.0603 \\
\hline & $(0.97)$ & $(0.09)$ & $(1.45)$ & $(1.29)$ \\
\hline \multirow[t]{2}{*}{ US Postdocs_4 } & 0.1230 & 0.4069 & 0.0114 & 0.0949 \\
\hline & $(0.66)$ & $(0.24)$ & $(0.43)$ & $(0.58)$ \\
\hline \multirow[t]{2}{*}{ International Postdocs_4 } & $0.7408 * * *$ & $-3.1843^{*}$ & 0.0169 & $0.2826 *$ \\
\hline & $(5.11)$ & $(1.95)$ & $(0.59)$ & $(1.74)$ \\
\hline \multirow[t]{2}{*}{ Stock of US PhDs } & 0.1898 & $0.9814^{* * *}$ & $0.2351^{* * *}$ & $0.1422 * *$ \\
\hline & $(1.57)$ & $(3.02)$ & (3.94) & (2.29) \\
\hline \multirow[t]{2}{*}{$\begin{array}{l}\text { Stock of Permanent Resident } \\
\text { PhDs }\end{array}$} & 0.3831 & 0.9682 & $-0.5329 * * *$ & 0.2912 \\
\hline & $(1.00)$ & $(0.78)$ & (3.82) & (1.39) \\
\hline \multirow[t]{2}{*}{$\begin{array}{l}\text { Stock of Temporary Resident } \\
\text { PhDs }\end{array}$} & $-0.7582^{* * *}$ & -0.0955 & -0.0791 & -0.0660 \\
\hline & (5.27) & $(0.21)$ & $(0.96)$ & (1.27) \\
\hline \multirow[t]{2}{*}{ Stock of Other PhDs } & $-0.6384 * *$ & $3.4331^{* * *}$ & -0.1180 & $0.2471^{* * *}$ \\
\hline & $(2.10)$ & (3.29) & $(0.61)$ & $(2.90)$ \\
\hline \multirow[t]{2}{*}{ Technology Transfer Office } & $0.3295 * * *$ & $0.2391^{*}$ & $0.2038 * * *$ & $0.1846 * *$ \\
\hline & $(4.88)$ & (1.90) & (3.39) & $(2.40)$ \\
\hline \multirow[t]{2}{*}{ Top 25 in Chemical Field } & $0.3566^{*}$ & & & \\
\hline & $(1.65)$ & & & \\
\hline \multirow[t]{2}{*}{$\begin{array}{l}\text { Top } 25 \text { in Computer \& } \\
\text { Commun. }\end{array}$} & & $0.7269 * *$ & & \\
\hline & & $(2.57)$ & & \\
\hline \multirow[t]{2}{*}{ Top 25 Drug \& Medical } & & & $0.6346^{* * *}$ & \\
\hline & & & $(3.10)$ & \\
\hline \multirow[t]{2}{*}{$\begin{array}{l}\text { Top } 25 \text { in Electric, } \\
\text { Electronics \& Mech. }\end{array}$} & & & & $0.4803^{* * *}$ \\
\hline & & & & $(2.73)$ \\
\hline Minus Log Likelihood & 3497 & 1555 & 3598 & 2934 \\
\hline AIC & 7050 & 3164 & 7252 & 5924 \\
\hline $\mathrm{BIC}$ & 7213 & 3324 & 7416 & 6086 \\
\hline
\end{tabular}

Notes:
(a) Absolute value of t statistics within parentheses.
(b) $*, * *$ and $* * *$ indicate statistical significance at $10 \%, 5 \%$, and $1 \%$ respectively.
(c) All specifications control for year effects.
(d) Results for postdoc and PhD variables are expressed in 100s. 